Running head: SEAHORSE AQUACULTURE, BIOLOGY AND CONSERVATION

\title{
Seahorse Aquaculture, Biology and Conservation: Knowledge Gaps and Research Opportunities
}

Felipe P. A. Cohen ${ }^{1,2}$, Wagner C. Valenti ${ }^{1,2} *$, Miquel Planas ${ }^{3}$ and Ricardo Calado ${ }^{4 *}$

${ }^{1}$ UNESP - Univ Estadual Paulista, Centro de Aquicultura (CAUNESP). Via de Acesso

Prof. Paulo Donato Castellane s/n. 14884-9000. Jaboticabal, São Paulo, Brazil. (FPAC fcohen.bio@gmail.com;WCV - valenti@caunesp.unesp.br)

${ }^{2}$ Instituto de Biociências, Campus do Litoral Paulista - Univ Estadual Paulista,. Praça Infante Dom Henrique s/n. 11330-900. São Vicente, São Paulo, Brazil.

${ }^{3}$ Instituto de Investigaciones Marinas (CSIC), Eduardo Cabello 6. 36208 Vigo, Spain. (mplanas@iim.csic.es)

${ }^{4}$ Departamento de Biologia \& CESAM, Universidade de Aveiro, Campus Universitário de Santiago.3810-193. Aveiro, Portugal. (rjcalado@ua.pt)

*Corresponding author: WCV (valenti@caunesp.unesp.br) RC (rjcalado@hotmail.com) 


\section{ABSTRACT}

Seahorses are currently experiencing an unprecedented level of anthropogenic pressure promoted by habitat destruction and increasing fishing effort to supply premium markets. The present study provides an overview of the scientific literature on seahorses in the $21^{\text {st }}$ century and critically discusses five major knowledge gaps and research opportunities to advance the state of the art on this research field. The average number of publications per year increased from 10 (2001-2002) to 40 (2001-2015), the majority addressing issues on seahorse ecology, biology and aquaculture, with the most studied species being Hippocampus kuda, H. guttulatus, H. reidi, H. abdominalis, H. erectus, H. hippocampus, and H. trimaculatus. This study explores the opportunity of using seahorses as flagship species to foster mangrove conservation and decrease trawling fisheries. It also suggests that further scientific studies are needed to better understand and manage the populations of the most heavily traded seahorse species, as well as the need to monitor their vulnerability to emerging pollutants and climate change. Sustainable seahorse aquaculture can play an important role in seahorse conservation, as well as in the development of reliable traceability tools to fight the illegal trade of these highly priced organisms.

Keywords: bibliometry, seahorse trade, sustainability, sustainable aquaculture, marine ornamental species, threatened species. 


\section{INTRODUCTION}

Marine habitats are exposed to an unprecedented level of anthropogenic pressure, including unsustainable fishing, degradation and loss of habitat, pollution and global climate change (Pan et al., 2013). For successful conservation actions and plans, the perception of marine conservation issues must raise awareness on a broader community level. Most threats to marine habitats will only be mitigated through a change in human behaviour through educational and awareness-raising actions, which has been the greatest challenge faced by conservationists (Wright et al., 2015).

Marketing tools have been successfully used to influence human behaviour in favour of conservation (Wright et al., 2015). A common marketing approach in biological conservation is the use of flagship species. Flagship species (sensu Heywood, 1995 and Walpole and Leader-Williams, 2002) are species that can be used as symbols in conservation campaigns to raise awareness and funding for specific conservation issues. The use of a particular species (or group of species) as flagship can benefit its conservation and the protection of its habitat and other associated species. Several features may qualify a species as a suitable flagship, as long as it appeals to the target audience, to the conservation issue being addressed and to the local context (Bowen-Jones and Entwistle, 2002; Home et al., 2009; Verissimo et al., 2011). Some charismatic features may favour the selection of a given species as flagship (Home et al., 2009). An example is the seahorses (Shokri et al., 2009; Vincent et al., 2011; Yasue et al., 2012), with their unique morphology similar to ponies and their reproduction mode, in which the males incubate the eggs in an abdominal chamber. 
Currently, 54 extant species of seahorses are taxonomically recognized as valid, all within a single genus: Hippocampus (according to World Register of Marine Species available at: <http://www.marinespecies.org/>; accessed in March 2016). Most of these species live in association with seagrasses and mangroves, as well as macroalgae, sponges and corals, generally within the shallow waters of tropical and temperate, and exceptionally in deeper habitats regions (Foster and Vincent, 2004; Kuiter, 2009). Seahorses are vulnerable species because of their habitat degradation (Vincent et al., 2011; Harasti, 2016) and also due to the collection of millions of specimens every year to supply the traditional Chinese medicine and, to a lower extent, the marine aquarium and curio trade (Vincent et al., 2011; Foster et al., 2016). Indeed, habitat degradation and the pressure arising from illegal, unreported and unregulated collection of seahorses worldwide prompted the inclusion of all Hippocampus species into CITES (the Convention on International Trade in Endangered Species of Wild Fauna and Flora) Appendix II in 2002 - a decision that became effective in 2004 (CITES, 2004).

The above rationale is the main driver that encourages scientists worldwide to investigate seahorses. The aim of this study was to provide a critical overview on the scientific literature addressing seahorses in the $21^{\text {st }}$ century and discuss research opportunities and gaps of knowledge on these remarkable organisms.

\section{DATA SURVEY}

In March 2016, a survey was conducted using all databases of Thomson Reuters ${ }^{\mathrm{TM}}$ Web of Science $^{\mathrm{TM}}$ (available at: http://apps.webofknowledge.com) to collect all references related to seahorses (Actinopterygii: Syngnathidae) published from 2001 to 2015. The term 
"seahorse" was used in the "Topic" field to conduct the search. Except for patents, all types of publications (scientific journals, book chapters, meetings abstracts, magazines, and short communications) were used for the analyses. A total of 796 references were retrieved, with each one of them being screened individually to determine whether they were within the scope of this study. Most of the excluded references were studies that used the word seahorse in a context other than the fish (e.g., seahorse extracellular flux analyzer).

Selected references were included in a gross table containing first author, title, year, journal, and country for both the first and last authors (as these are commonly the corresponding authors). If the first authors were affiliated with more than one country, the publication was considered as originating from both of them. The scientific name of the seahorse species studied was also annotated (according to the World Register of Marine Species - available at: <http://www.marinespecies.org/>; accessed in March 2016) and each reference was assigned to up to three different research fields. A total of 10 different research fields were selected to assign each reference: aquaculture, biology, conservation, ecology, morphology, pathology, pharmacology, physiology, taxonomy, and trade. The rationale employed to assign a given reference to a specific research field is detailed in Table 1. Whenever the publication did not detail the name of the species being addressed in the title or abstract, and it was not possible to gain access to the original text of the publication, it was registered the name as "Absent". When studies addressed too many species (more than eight) or was a "broad scope" publication addressing seahorses in a generalist way (e.g., did not detail any species in particular) they were registered as "Hippocampus spp.". 
Overall scientific production on seahorses per year was used to assemble a frequency distribution histogram, which also included the cumulative frequency. To provide an overview of the most published topics on seahorses, all titles were plotted in a word cloud (program available at: <http://www.wordclouds.com>; accessed in March 2016). The principle of a word cloud is simple, in which the size of the word is related to its frequency of appearance in the titles of publications. To make the word cloud more informative, the four most repeated (and not informing) words and its derivatives were eliminated: "Hippocampus" (Genus), "Seahorse”, "Syngnathidae”, and "Species”. Popular names, whenever followed by scientific names, were also eliminated.

The percentage of the most studied species and research fields was calculated, as well as the total number of publications produced per country, while also discriminating per research field. Because the percentage of countries to which the $1^{\text {st }}$ and the last author were affiliated was similar $(\sim 88 \%)$, only the $1^{\text {st }}$ author's country was used for analysis. Additional histograms of frequency distribution were made to highlight the top 10 journals publishing research on seahorses, as well as which seahorse species have been addressed in scientific literature across different research fields.

To end the critical review of scientific literature of seahorses during the period being covered (2001-2015), five knowledge gaps and research opportunities were identified and guidelines for future studies are presented.

\section{SEAHORSE SCIENTIFIC LITERATURE PUBLISHED IN THE $21^{\text {ST }}$ CENTURY}

A total of 423 publications retrieved were relevant for this study and selected for analysis (see Table S1 on supplementary information). In spite of their recognised iconic character, 
the knowledge on biology of seahorses was scarce before the present century. Over the past 15 years (2001 to 2015) there has been an increase in the number of scientific publications addressing seahorses, with the average number of publications per year raising from 10 in 2001-2002 to $\sim 40$ in 2001-2015 (Fig. 1). This increase in scientific publications may be related to the inclusion of seahorses in CITES Appendix II. The need for scientific data to support regulation and management decisions may have promoted research effort towards seahorse-related topics. Therefore, the inclusion of seahorses in this list has contributed to their conservation (Foster et al., 2016), and scientific knowledge.

Thirty-five species of Hippocampus were referenced in at least one of the publications selected for this study, which covers $65 \%$ of all extant species of seahorses. Nonetheless, most publications retrieved (76\%) are focused on only seven species $(\sim 13 \%$ of all extant species) (Fig. 2). From these seven species, three are among the most heavily traded, either dried for traditional Chinese medicine (H. trimaculatus and H. kuda) or live for aquariums (H. kuda and H. reidi) (Foster et al., 2016). This finding shows a trade-driven research effort on these species. Seahorses were included in traditional Chinese medicine probably more than 600 years ago (Vincent, 1996). The trade of live seahorses for marine aquariums is more recent, dating to the early 1900 's, with the beginning of the marine ornamental trade (Vincent, 1996; Wood, 2001). Trade regulation and management claims for scientific data, namely in the fields of ecology and biology (Fig. 2). Thus, it is expected that some of the heavily traded species to be among the ones most addressed by scientific research. Additionally, the increasing demand for knowledge on genus Hippocampus may prompt other countries to conduct research on species occurring in their national waters, 
even if not significantly traded (e.g., $H$. erectus in the USA, $H$. guttulatus and $H$. hippocampus in EU countries, and H. abdominalis in Australia).

The word cloud highlighted the most common words recorded on the titles of the publications selected for this study (Fig. 3). As expected, the names of the seven most studied seahorse species ranked among the most repeated words. Other words highlighted in the word cloud are mostly related to seahorse aquaculture and unique features. Among these, it is possible to see the words "growth", "juvenile", "feeding" "survival", "development", "fed", "Artemia", "cultured" and "diet", which clearly refer to some of the bottlenecks in seahorse aquaculture (e.g., rearing of early life stages) (Koldewey and Martin-Smith, 2010; Olivotto et al., 2011). The growing awareness and concern for the global trade of seahorses and conservation were drivers fostering research reflected by words such as "population", "conservation", "trade", "threatened" and "habitat". The role of the male in brood care and pregnancy, along with the upright body position displayed by seahorses and their unusual flexibility - for a fish whose body is covered by bony plates have inspired many studies reflected by the words "male", "reproductive", "pregnancy", "pouch", "morphological", and "tail". Finally, words such as "genetic", "mitochondrial", "molecular", "microsatellite", and "evolution" were also commonly recorded among titles because of the increasing number of studies using genetic tools for seahorse taxonomy, evolution, population structure, and distribution.

Based on the affiliation country of the first author, forty-three countries published at least one scientific publication addressing seahorse since 2001; however, nine countries accounted for more than $60 \%$ of all publications (Fig. 4). Canada and the USA produced the most in this century (Fig. 4). From a continental perspective, Europe represented 33\% 
of all publications followed by Asia (26\%), North America (21\%), Oceania (10\%), South America (8\%), and Africa (1\%). Publications on ecology, trade, and conservation were mostly from Canada (Fig. 4). This country held one of the head offices of the Project Seahorse, which is the largest seahorse conservation group in the world. Members of Project Seahorse have contributed a significant number of scientific publications addressing different species of Hippocampus (available at: <http://www.projectseahorse.org/>; accessed in March 2016). China was the leading country on publications addressing seahorse aquaculture, followed by Spain, the USA, and Australia (Fig. 4). Most scientific studies on seahorse morphology were from Belgium, followed by the USA (Fig. 4). Publications on pathology were mostly from Spain, followed by the USA and India (Fig. 4). Studies on pharmacology were performed only in Asia, where seahorses are used for medicinal purposes.

The Journal of Fish Biology (Wiley-Blackwell) and Aquaculture (Elsevier Science

B.V.) were the scientific journals, indexed in Thomson Reuters ${ }^{\mathrm{TM}}$ Web of Science $^{\mathrm{TM}}$, which published more studies addressing seahorses in this century, accounting for $17 \%$ of all publications on this topic (Fig. 5). Aquaculture, Journal of the World Aquaculture Society (Wiley-Blackwell), and Aquaculture Research (Wiley-Blackwell) published $60 \%$ of all publications on seahorse aquaculture.

\section{KNOWLEDGE GAPS AND RESEARCH OPPORTUNITIES}

The critical analysis of the information retrieved from this survey revealed five major knowledge gaps and research opportunities that are essential to advance the state of the art on seahorse research: (1) Maximizing the potential of seahorses as flagship species for 
marine conservation; (2) Filling knowledge gaps on the most traded seahorse species; (3) Understanding the potential impact of emerging pollutants and climate change on seahorses; (4) Developing a sustainable low-cost aquaculture of seahorses; (5) Improving the traceability of traded seahorses to foster marine conservation.

\section{Maximizing the potential of seahorses as flagship species for marine conservation}

The unique morphology and reproduction makes seahorses charismatic animals. These features suggest that they could be good flagship species for marine conservation. Nonetheless, more than charismatic, a flagship species should fit a specific goal on conservation, in line with local context (Bowen-Jones and Entwistle, 2002; Home et al., 2009). According to Verissimo et al. (2011), flagship species are "species used as the focus of a broader conservation marketing campaign based on its possession of one or more traits that appeal to the target audience." Therefore, the question that should be investigated is whether the marketing strategies based on seahorse images are efficient enough to raise awareness on people for a specific conservation issue and allow the raising of enough funding to support it.

Seahorses inhabit many tropical and temperate shallow water habitats around the globe, including coral reefs, mangroves, and seagrass beds (Kuiter, 2009; Foster and Vincent, 2004). These areas are among the most affected areas in the sea, mainly through fishing, pollution, and tourism (Alongi, 2002; Hughes et al., 2003; Waycott et al., 2009). It has been shown that Syngnathids can be efficient flagship species for estuarine seagrass beds conservation, using as rationale that some additional species can also benefit from seahorse conservation (Shokri et al., 2009). Indeed, Project Seahorse also showed the 
effective use of seahorses as flagship species through the creation of some marine protected areas in central Philippines (Vincent et al., 2011). Nonetheless, further studies are still needed to link seahorses to their habitats and evaluate the true potential of them as flagship species, as well as on marketing strategies featuring these species. An urgent goal could be the use of seahorses to promote mangrove conservation. Mangroves are recognised as key marine habitats being amongst some of the most threatened tropical ecosystems (Alongi, 2002). Regions where mangroves are inhabited by seahorses (e.g., H. reidi in Brazil and $H$. kuda in Southeast Asia) (Foster and Vincent, 2004) should be associated with the species and studies on their potential as flagship to foster habitat conservation should be performed. Another goal that could benefit from seahorse image would be the conservation of costal seabed through the reduction of destructive trawling fisheries (namely for shrimp). Study the feasibility of raising awareness of wild shrimp consumers by a "seahorse safe" labeldeveloping and promoting fishing practices that do not harm seahorse populations. If costumers change their preference for a product originating from a more responsible fishing practices (e.g. "seahorse safe"), it can certainly affect the whole shrimp supply and value chain, and even benefit other marine species.

\section{Filling knowledge gaps on the most traded seahorse species}

Five seahorse species (H. trimaculatus, H. spinosissimus, H. kelloggi, H. kuda, and H. algiricus) account for more than $90 \%$ of the world trade of seahorses (Fig. 6), with most being traded as dried specimens collected from the wild (Foster et al., 2016). Except for $H$. $k u d a$, scientific studies addressing these species are scarce (Fig. 6). On the other hand, $H$. $k u d a$ and $H$. reidi, species that are more well represented in the marine aquarium trade, 
have greatly been subject to scientific studies, namely in the field of aquaculture (Fig. 6). Even though not significantly traded internationally, $H$. erectus, $H$. abdominalis, $H$. guttulatus, and H. hippocampus are often referred as potential species for the marine aquarium trade (Koldewey and Martin-Smith, 2010) and have been widely studied (Fig. 6). Therefore, the aquarium trade has driven scientific research of seahorses, especially their aquaculture (Fig. 6). The higher prices fetched by live specimens, when compared to dried ones (Koldewey and Martin-Smith, 2010), may be the reason of this bias. In some way, it is puzzling that research efforts are not being target towards the most heavily traded species.

Current aquaculture practices are not economically feasible for seahorses demanded by traditional Chinese medicine because of the low market price. Nevertheless, low-cost production of seahorse may be feasible and profitable (Fonseca et al., 2015). Thus, studies addressing the development of low-cost production systems should be prioritized. Additionally, studies addressing the population and fishery biology of the traded species should also be promoted to allow a better management of the fisheries, ensuring the maintenance of natural stocks and species conservation. Except for $H$. algiricus that is from West Africa, all other four most traded seahorse species are distributed across Southeast Asia (Foster and Vincent, 2004). Therefore, research focusing on the topics referred above (aquaculture and population biology) should be encouraged in Asian countries and be prioritized in international funding programs targeting marine conservation.

Transport is one of the highest costs in marine ornamental production, especially in countries where air shipping is necessary. Nevertheless, papers focus on transport of live seahorses are very scarce. An experiment conducted with $H$. abdominalis showed that it can tolerate extensive handling and confinement up to 35 hours of transportation (Wrigth et 
al., 2007). This shows a good opportunity to test the density during transport, since more animals in the same bag would significantly reduce freight. Cunha et al. (2011) showed that essential oil of Lippia alba can be an effective anesthetic for slight sedation and transport of H. reidi. No information on the effect of the micro environment inside bags is available. Seahorses are very low swimmers, have an efficient visual system, and use their camouflage for protection. Thus, the use of some specific colors background and inert substrates might reduce stress during transport, increasing survival, animal health and welfare. Studies on transportation of traded species are certainly an important avenue for new research. The optimization in this step may bring significant economic benefits and contribute to the animal welfare.

Some highly traded species lack of essential information for conservation. It is widely accepted that seahorse populations are threatened by overexploitation, bycatch, and generalized habitat degradation (Vincent et al., 2011; Harasti, 2016). Nonetheless, 67\% of the 40 species included in the IUCN red list are classified as "Data Deficient" (IUCN, 2015-4). Only 11 species are categorised as "Vulnerable" and one as "Endangered" $(H$. capensis) (IUCN, 2015-4). Four of the seven most studied species are within the "Data Deficient" category (Fig. 6). Yet, most traded species are classified as "Vulnerable" (Fig. 6), probably based only on trade and fisheries quantification (Perry et al., 2010). The species H. reidi is highly traded for marine aquariums, but is classified as "Data Deficient" although many research efforts have been made to study this species. The "IUCN Seahorse, Pipefish and Stickleback Specialist Group" has developed significant efforts to provide information to improve the conservation of these fish (available at: https://iucnseahorse.org; accessed in May 2016). Nonetheless, there are still knowledge gaps on 
growth, maximum size, longevity, reproduction biology, population structure and distribution, and population size of the most traded species. Overall, there are gaps on ecological and biological data from wild populations that needs to be overcome to promote regulations for a more sustainable fishery and conservation. Particularly, studies on time series in wild populations are imperative to ascertain the right assignment among IUCN categories and further conservation plans if required. Currently, there is not enough information to assess the endangerment status for most seahorse species.

\section{Understanding the potential impact of emerging pollutants and climate change on}

\section{seahorses}

The low swimming capacity, small home range and preference for coastal habitats, enhance the vulnerability of seahorses to pollution (Vincent et al., 2011; Delunardo et al., 2013) and susceptibility to climate change (Faleiro et al., 2015). Nevertheless, seahorses may thrive in polluted areas (Tiralongo and Baldacconi, 2014) and even increase their populations (Correia et al., 2015). Exposure to crude oil has been studied in seahorses (Delunardo et al., 2013). The authors reported that crude oil can damage $H$. reidi cells, but that at an exposure of $10 \mathrm{ml} / \mathrm{L}$ during a 14-day period was not enough to induce severe gill damage (Delunardo et al., 2013). Others studies revealed that seahorses can bioaccumulate organochlorine pesticide and heavy metals (Nenciu et al., 2014; Zhang et al., 2016), a feature that coupled with their low motility suggests that these organisms can be good bioindicators (Delunardo et al., 2015). Nonetheless, pollution type and its extent may vary in marine habitats and generalizations may lead to pitfalls in decision-making. Thus, it is therefore important to study the effect of pollution on seahorse individuals and populations to understand in which scenarios they might affected. Additionally, studies should address the bioaccumulation on 
seahorses used for traditional Chinese medicine, as pollution could hamper any potential medical benefits or even pose a risk to human health. There is a knowledge gap in ecotoxicology assays evaluating the vulnerability of seahorses to emerging pollutions, such as nanoparticles, microplastic, and drugs.

Climate change can affect fish in different levels, from organisms, to populations, communities, and spatial ecosystems (Koenigstein et al., 2016). The main effects of climate change on oceans is the rising of water temperature, sea level, and acidification. Seahorse low motility might hamper migration from a changing environment, which would require adaptation to survive. The dependency of many seahorse species on adequate subtracts, mainly certain species of macroalgae and seagrass, would certainly be affected by the availability of anchoring elements and the composition, density and distribution of natural prey (strongly dependent on the type of vegetation) in temperature rising environments. Therefore, the biogeographical distribution of seahorse species could be altered (Planas et al., 2012). It was demonstrated that the combined effects of ocean warming and acidification negatively affect the behaviour and physiology of adult $H$. guttulatus (Faleiro et al., 2015). Further studies are therefore necessary to monitor the impact of climate change in seahorses because of their unique breeding strategy, and the broad distribution of the genus from temperate to tropical regions, including habitats where fish can be more resistant to climate change (e.g., estuaries) (Perry et al., 2015). Early life stages of some fish show abnormal calcification of otoliths (Munday et al., 2011) and skeleton (Pimentel et al., 2014) when exposed to acidification. The impact on seahorses should be investigated mainly because their bony plates are essential for protection against predation and their prehensile tail plays a key role in their stability in benthic substrates. Moreover, the paternal 
osmoregulation of pouch salinity in seahorses (Stölting and Wilson, 2007) is a feature that may also be affected under climate change scenarios and may negatively affect the offspring fitness.

\section{Developing a sustainable low-cost aquaculture of seahorses}

Although aquaculture of marine ornamental species is often presented as an option to relieve the collection of specimens from the wild, it can also drive negative environmental and social impacts (Tlusty, 2002). As an example, H. reidi, a West Atlantic species that has been mostly cultured in Sri Lanka (Foster et al., 2016), a practice that may promote ecological issues through escapees (Vincent et al., 2011). The increase of captive bred seahorses in the trade(Foster et al., 2016) should make researchers consider the sustainability of these practices as a whole and not solely focus on the reduction of fishing effort targeting natural populations.

Most studies and commercial aquaculture practices of seahorses rely on the use of intensive monoculture systems, with animals being kept in aquariums or tanks under controlled water parameters and being totally depended on exogenous feeding to thrive. A system that depends exclusively on exogenous feeding might be inefficient for species that are difficult to feed, as seahorses have no stomach and this feature can reduce their ability to digest non-natural diets (Palma et al., 2014). Therefore, systems that could somehow allow the provisioning of natural food might be more sustainable than those currently used and even promote better results. An example is the cage-culture approach within an integrated multi-trophic aquaculture (IMTA) system. Some seahorse species can support a relatively high range of salinity (euryhaline) and temperature (eurythermal) (Hilomen- 
Garcia et al., 2003; Wong and Benzie, 2003; Curtis and Vincent, 2005; Lin et al., 2009; Hora et al., 2016), which makes them good candidates for cage-culture production in coastal areas, including coastal lagoons and estuaries. The natural growth of a periphytonbased community in the nets of grow-out cages, along with the natural flow-through of wild plankton, are suitable sources of natural food. Pilot trials have reported promising results during the grow-out of $H$. reidi in floating cages inside ponds destined for penaeid shrimp and oyster production (Fonseca et al., 2015). The authors reported a mean survival of $\sim 80 \%$, with seahorses attaining commercial size $(7-8 \mathrm{~cm})$ within approximately three months at a density of 40 ind. $\mathrm{m}^{-3}$ and without the input of any exogenous food. By growing $H$. reidi in an IMTA system already used to address the production of penaeid shrimp and oysters, seahorse aquaculture could be labelled as low-cost and economically feasible (Fonseca et al., 2015). Xu et al. (2010) have also shown that the integration of macroalgae (Chaetomorpha $\mathrm{sp}$ ) grow-out in the production system increases survival and growth of juvenile $H$. erectus. Future studies addressing low-cost production systems should be supported, as this approach can also provide an opportunity to low-income coastal communities and make conservation efforts more perceptible at a local and regional scale. By enrolling local communities into such aquaculture practices, it can be possible to contribute towards a decrease of illegal, unregulated, and undeclared collection of seahorses from the wild and enhance environmental and social sustainability. Such enrolment would certainly require a simplification of the rearing system.

\section{Improving the traceability of traded seahorses to foster marine conservation}


Seahorses are the only group of marine ornamental fish traded to supply the aquarium industry that is currently included in CITES Appendix II (Vincent et al., 2014; Foster et al., 2016). This aspect puts seahorses in the forefront of trade regulations and management disputes. Nonetheless, there is still a substantial mismatch in species and volumes reported by CITES export and import records (Foster et al., 2016), with no method being currently available to confirm the origin of collection, nor to differentiate wild-caught from captive bred seahorses. Recently, the export of H. algiricus, one of the top five most traded species (Foster et al., 2016), was banned from Senegal and Guinea (Project Seahorse, 2016) and further restrictions can be anticipated to the trade of others seahorse species in the future. As captive cultured specimens are under less restricting regulations, these may be an alternative to fulfil demand. Nonetheless, without a reliable traceability toolbox, neither cultured specimens, nor those originating from sustainable collection, can be successfully discriminated from specimens illegally poached from the wild. Traceability is essential to enforce any conservation effort and avoid the collapse of their trade and the socioeconomic impacts this scenario may pose (Cohen et al., 2013).

Before fine tuning traceability methods for seahorses, it is essential to identify the end market. Seahorses have two key and very distinct markets: the trade of millions of dried specimens for human consumption (traditional Chinese medicine) and the trade of thousands of live specimens for marine aquariums (Foster et al., 2016). Clearly, this dichotomy between markets requires different traceability methods and strategies for their implementation. The traceability of dried seahorses may be more easily achieved through the use of geochemical, biochemical, and molecular approaches already described for the seafood supply chain (Leal et al., 2015). Two studies highlighted the possibility to sample 
tissues from partial fin-clipping of seahorses for molecular and stable isotopes analysis (Valladares and Planas, 2012; Woodall et al., 2012). Nonetheless, the drying process of specimens may affect the reliability of some of these methods and further studies are required to validate their use. The fatty acid profile is a promising tool for geographical traceability of seafood (Leal et al., 2015), and might be suitable to trace dried seahorse. Previous biochemical analysis showed significant difference on fatty acids composition among six seahorse species from the coast of China (Lin et al., 2008). Recently, Shen et al. (2016) developed and validated a sensitive and specific lipidomic protocol for the detection of phospholipids in dried seahorses. The authors were able to differentiate five wild species of dried seahorse based on phospholipid class. Therefore, future studies should investigate the reliability of this method to differentiate wild seahorses from captive bred ones, and to differentiate specimens from the same species originating from different origins (regions or farms). Concerning the trade of live seahorses to supply marine aquariums worldwide, the production of different colour morphs and shapes through hybridization might be a good way to differentiate captive bred seahorses. Two scientific studies reported interspecific hybridization in seahorses so far, one between male $H$. algiricus and female $H$. hippocampus (Otero-Ferrer et al., 2015), and other between male $H$. erectus and female $H$. redi (Ho et al., 2015). This method however poses environmental risks due to potential escapees (Cohen et al., 2013). The use of bacterial communities-based signatures present in fish mucus for their origin traceability has been addressed for marine fish in general (Leal et al., 2015) and marine ornamentals in particular (Cohen et al., 2013). The only study available to date on the phylogenetic characterization of bacterial communities associated with seahorses showed that the microbiological composition of the cutaneous mucus and 
that of both the surrounding seawater and the live food differ significantly (Balcázar et al., 2010). The low motility of seahorses may favour the use of this approach to differentiate wild populations, as well as wild and cultured specimens, in a non-invasive and nondestructive way. It is reasonable to assume that even in the wild, seahorses would stay in the same geographic area long enough to develop a local-specific bacterial signature in their mucus that may be used for traceability. With the advent of a reliable traceability method for seahorses, certification and eco-labelling could be implemented by CITES to trace animals throughout the whole supply chain, supporting a conscious and more sustainable trade.

\section{CONCLUDING REMARKS}

A multitude of factors may motivate researchers to study seahorses. Nonetheless, it is important to flag the paramount research fields to advance the state of the art to subsidize decision makers to address the issues affecting production, trade and upkeep the natural populations. This study highlights five knowledge gaps and research opportunities that can generate information to supply dry and live markets and promote seahorse conservation. Overall, a well-managed and sustainable trade of these emblematic marine organisms includes sustainable fisheries and aquaculture. Research should provide science-based information to develop a sustainable industry. This can contribute to marine conservation and foster socio-economic activities in developing regions.

\section{ACKNOWLEDGMENTS}


The present work is dedicated to the memory of Professor Junda Lin, colleague and friend, for his contributions to seahorse research and for advocating an $\mathrm{ABC}$ approach to advance the state of the art: Aquaculture, Biology and Conservation. We thank the São Paulo Research Foundation - FAPESP (grants \# 2013/22260-6 and 2015/18050-0) and The National Council for Scientific and Technological Development - CNPq (grants \# 441356/2014-1) for the financial support provided. Thanks are also to FCT/MEC through national funds, and the co-funding by the FEDER, within the PT2020 Partnership Agreement and Compete 2020 for the financial support to CESAM (UID/AMB/50017/2013). We also thank Ligia K. Cohen for helping with the figures.

\section{REFERENCES}

Alongi, D. M. Present state and future of the world's mangrove forests. Environ. Conserv., 29: $331-349$ (2002).

Balcázar, J. L., N. M. Lee, J. Pintado and M. Planas. Phylogenetic characterization and in situ detection of bacterial communities associated with seahorses (Hippocampus guttulatus) in captivity. Syst. Appl. Microbiol., 33: 71-77 (2010).

Bowen-Jones, E. and A. Entwistle. Identifying appropriate flagship species: the importance of culture and local contexts. Oryx, 36: 189-195 (2002).

Cohen, F. P. A., W.C. Valenti and R. Calado. Traceability issues in the trade of marine ornamental species. Rev. Fish. Sci., 21: 98-111 (2013).

Correia, M., I. R. Caldwell, H. J. Koldewey, J. P. Andrade and J. Palma. Seahorse (Hippocampinae) population fluctuations in the Ria Formosa Lagoon, south Portugal. J. Fish Biol., 87: 679-690 (2015). 
CITES. Trade in sehorses: implementation of Decision 12.54 in Notification to the Parties Vol. 2004/033 (2004).

Cunha, M. A., B. F. Silva, F. A. Cariello Delunardo, S. C. Benovit, L.C. Gomes, B. M. Heinzmann and B. Baldisserotto. Anesthetic induction and recovery of Hippocampus reidi exposed to the essential oil of Lippia alba. Neotrop. Ichthyol., 9: 683-688 (2011).

Curtis, J. M. R. and A. C. J. Vincent. Distribution of sympatric seahorse species along a gradient of habitat complexity in a seagrass-dominated community. Mar. Ecol.Prog. Ser., 291: 81-91 (2005).

Delunardo, F. A., B. F. Silva, M. G. Paulino, M. N. Fernandes and A. R. Chippari-Gomes. Genotoxic and morphological damage in Hippocampus reidi exposed to crude oil. Ecotox. Environ. Safe., 87: 1-9 (2013).

Delunardo, F. A., L. R. Carvalho, B. F. Silva, M. Galao, A. L. Val, A. R. Chippari-Gomes. Seahorse (Hippocampus reidi) as a bioindicator of crude oil exposure. Ecotox. Environ. Safe., 117: 28-33 (2015).

Faleiro, F., M. Baptista, C. Santos, M. Aurélio, M. S. Pimentel, M. Pegado, J. Paula, R. Calado, T. Repolho and R. Rosa. Seahorses under a changing ocean: the impact of warming and acidification on the behaviour and physiology of a poor-swimming bony-armoured fish. Conserv. Phys., 3: 1-7 (2015).

Fonseca, T., F. David, F. Ribeiro, A. Wainberg and W. C. Valenti. Technical and economic feasibility of integrating seahorse culture in shrimp/oyster farms. Aquac. Res., 1-10 (2015). 
Foster, S. J. and A. C. J. Vincent. Life history and ecology of seahorses: implications for conservation and management. J. Fish Biol., 65: 1-61 (2004).

Foster, S. J., S. Wiswedel and A. C. J. Vincent. Opportunities and challenges for analysis of wildlife trade using CITES data - seahorses as a case study. Aquat. Conserv.-Mar. Freshw. Ecosyst., 26: 154-172 (2016).

Harasti, D. Declining seahorse populations linked to loss of essential marine habitats. Mar. Ecol.-Prog. Ser., 546: 173-181 (2016).

Heywood, V. H. Global biodiversity assessment. Cambridge University Press (1995)

Hilomen-Garcia, G. V., R. Delos Reyes and C. M. H Garcia. Tolerance of seahorse Hippocampus kuda (Bleeker) juveniles to various salinities. J. Appl. Ichthyol., 19: 94-98 (2003).

Ho, N., A. Ho, G. Underwood, A. Underwood, D. Zhang and J. Lin. A simple molecular protocol for the identification of hybrid Western Atlantic seahorses, Hippocampus erectus $\times H$. reidi, and potential consequences of hybrids for conservation. J. Zoo Aquarium Res., 3: 11-20 (2015).

Home, R., C. Keller, P. Nagel, N. Bauer and M. Hunziker. Selection criteria for flagship species by conservation organizations. Environ. Conserv., 36: 139-148, (2009).

Hora, M. S. C., J.-C. Joyeux, R. V. Rodrigues, L. P. Souza-Santos, L. C. Gomes and Tsuzuki, M. Y. Tolerance and growth of the longsnout seahorse Hippocampus reidi at different salinities. Aquaculture, 463: 1-6 (2016).

Hughes, T. P., A.H. Baird, D. R. Bellwood, M. Card, S. R. Connolly, C. Folke, R. Grosberg, O. Hoegh-Guldberg, J. B. C. Jackson, J. Kleypas, J. M. Lough, P. Marshall, M. Nystrom, S. R. Palumbi, J. M. Pandolfi, B. Rosen and J. Roughgarden. 
Climate change, human impacts, and the resilience of coral reefs. Science, 301: 929933 (2003).

IUCN. The IUCN red list of threatned species (2015-4). Aviable at: $<$ http://www.iucnredlist.org/> (Accessed: May 2016)

Koenigstein, S., F. Mark, S. Goßling-Reisemann, H. Reuter and H. Poertner. Modelling climate change impacts on marine fish populations: process-based integration of ocean warming, acidification and other environmental drivers. Fish. Fish., 1-33 doi: 10.1111/faf.12155 (2016).

Koldewey, H. J. and K. M. Martin-Smith. A global review of seahorse aquaculture. Aquaculture, 302: 131-152 (2010).

Kuiter, R. H. Seahorses and their relatives. Aquatic Photografics (2009).

Leal, M. C., T. Pimentel, F. Ricardo, R. Rosa and R. Calado. Seafood traceability: current needs, available tools, and biotechnological challenges for origin certification. Trends Biotechnol., 33: 331-336 (2015).

Lin, Q., J. Lin, J. Lu and B. Li. Biochemical composition of six seahorse species, Hippocampus sp., from the Chinese coast. J. World Aquacult. Soc., 39: 225-234 (2008).

Lin, Q., J. Lin and L. Huang. Effects of substrate color, light intensity and temperature on survival and skin color change of juvenile seahorses, Hippocampus erectus Perry, 1810. Aquaculture, 298: 157-161 (2009).

Munday, P. L., V. Hernaman, D. L. Dixson and S. R. Thorrold. Effect of ocean acidification on otolith development in larvae of a tropical marine fish. Biogeosciences, 8: 1631-1641 (2011). 
Nenciu, M. I., V. Coatu, A. Oros, D. Rosioru, D. Tiganus and N. Rosoiu. Pollutant bioaccumulation in the long-snouted seahorse at the Romanian Coast. J. Environ. Prot. Ecol., 15: 1650-1659 (2014).

Olivotto, I., M. Planas, N. Simões, G. J. Holt, M. A. Avella and R. Calado. Advances in breeding and rearing marine ornamentals. J. World Aquacult. Soc., 42: 135-166 (2011).

Otero-Ferrer, F., R. Herrera, A. Lopez, J. Socorro, L. Molina and C. Bouza. First records of Hippocampus algiricus in the Canary Islands (north-east Atlantic Ocean) with an observation of hybridization with Hippocampus hippocampus. J. Fish Biol., 87: 1080-1089 (2015).

Palma, J., D. P. Bureau and J. P. Andrade. The effect of diet on ontogenic development of the digestive tract in juvenile reared long snout seahorse Hippocampus guttulatus. Fish Physiol. Biochem., 40: 739-750 (2014).

Pan, J., M. A. Marcoval, S. M. Bazzini, M. V. Vallina and S. G. Marco. Coastal marine biodiversity challenges and threats, pp. 43-67. In: Marine Ecology in a Changing World. (Arias, A. H. and M. C. Menendez, Eds.): CRC Press (2013).

Perry, A. L., K. E. Lunn and A. C. J. Vincent. Fisheries, large-scale trade, and conservation of seahorses in Malaysia and Thailand. Aquat. Conserv.-Mar. Freshw. Ecosyst., 20: 464-475 (2010).

Perry, D. M., D. H. Redman, J. C. Widman Jr., S. Meseck, A. King and J. J. Pereira. Effect of ocean acidification on growth and otolith condition of juvenile scup, Stenotomus chrysops. Ecol. Evol., 5: 4187-4196 (2015). 
Pimentel, M. S., F. Faleiro, G. Dionisio, T. Repolho, P. Pousao-Ferreira, J. Machado and R. Rosa. Defective skeletogenesis and oversized otoliths in fish early stages in a changing ocean. J. Exp. Biol., 217: 2062-2070 (2014).

Planas, M., A. Blanco, A. Chamorro, S. Valladares and J. Pintado. Temperature-induced changes of growth and survival in the early development of the seahorse Hippocampus guttulatus. J. Exp. Mar. Biol. \& Ecol., 438: 154-162 (2012).

Project Seahorse. Project Seahorse work drives new trade bans for West African seahorse hotspots. Available at: <http://www.projectseahorse.org/news/2016/4/4/new-tradebans-announced-for-west-african-seahorse-hotspots> (Accessed: May 2016)

Shen, Q., Z. Dai, Y.-W. Huang and H.-Y. Cheung. Lipidomic profiling of dried seahorses by hydrophilic interaction chromatography coupled to mass spectrometry. Food Chem., 205: 89-96 (2016).

Shokri, M. R., W. Gladstone and J. Jelbart. The effectiveness of seahorses and pipefish (Pisces: Syngnathidae) as a flagship group to evaluate the conservation value of estuarine seagrass beds. Aquat. Conserv.-Mar. Freshw. Ecosyst., 19: 588-595 (2009).

Stölting, K. N. and A. B. Wilson. Male pregnancy in seahorses and pipefish: beyond the mammalian model. Bioessays, 29: 884-896 (2007).

Tiralongo, F. and R. Baldacconi. A conspicuous population of the Long-Snouted Seahorse, Hippocampus guttulatus (Actinopterygii : Syngnathiformes : Syngnathidae), in a higly polluted mediterranean coastal lagoon. Acta Ichthyol. Piscat., 44: 99-104 (2014). 
Tlusty, M. The benefits and risks of aquacultural production for the aquarium trade. Aquaculture, 205: 203-219 (2002).

Valladares, S. and M. Planas. Non-lethal dorsal fin sampling for stable isotope analysis in seahorses. Aquat. Ecol., 46: 363-370 (2012).

Verissimo, D., D. C. MacMillan and R. J. Smith. Toward a systematic approach for identifying conservation flagships. Conserv. Lett., 4: 1-8 (2011).

Vincent, A. C. J. The international trade in seahorses. TRAFFIC International (1996).

Vincent, A. C. J., S. J. Foster and H. J. Koldewey. Conservation and management of seahorses and other Syngnathidae. J. Fish Biol., 78: 1681-1724 (2011).

Vincent, A. C. J., Y. J. S. Mitcheson, S. L. Fowler and S. Lieberman. The role of CITES in the conservation of marine fishes subject to international trade. Fish. Fish., 15: 563592 (2014).

Walpole, M. J. and N. Leader-Williams. Tourism and flagship species in conservation. Biodivers. Conserv., 11: 543-547 (2002).

Waycott, M., C. M. Duarte, T. J. B. Carruthers, R. J. Orth, W. C. Dennison, S. Olyarnik, A. Calladine, J. W. Fourqurean, K. L. Heck Jr., A. R. Hughes, G. A. Kendrick, W. J. Kenworthy, F. T. Short and S. L. Williams. Accelerating loss of seagrasses across the globe threatens coastal ecosystems. Proc. Natl. Acad. Sci. U. S. A., 106: 1237712381 (2009).

Wong, J. M. and J. A. H. Benzie. The effects of temperature, Artemia enrichment, stocking density and light on the growth of juvenile seahorses, Hippocampus whitei (Bleeker, 1855), from Australia. Aquaculture, 228: 107-121 (2003). 
Wood, E. Collection of coral reef fish for aquaria: global trade, conservation issues and managment strategies. Marine Conservation Society (2001).

Woodall, L. C., R. Jones, B. Zimmerman, S. Guillaume, T. Stubbington, P. Shaw and H. J. Koldewey. Partial fin-clipping as an effective tool for tissue sampling seahorses, Hippocampus spp. J. Mar. Biol. Assoc. U.K., 92: 1427-1432 (2012).

Wright, A. J., D. Verissimo, K. Pilfold, E. C. M. Parsons, K. Ventre, J. Cousins, R. Jefferson, H. J. Koldewey, F. Llewellyn and E. McKinley. Competitive outreach in the 21st century: Why we need conservation marketing. Ocean Coastal Manage, 115: 41-48 (2015).

Wright, K.A., C. M. C. Woods, B. E. Gray and P. M. Lokman. Recovery from acute, chronic and transport stress in the pot-bellied seahorse Hippocampus abdominalis. J. Fish Biol., 70: 1447-1457 (2007).

$\mathrm{Xu}, \mathrm{Y} ., \mathrm{J}$. Lin and S. Chen. Polyculture of the lined seahorse, Hippocampus erectus Perry, 1810 with two species of macroalgae in aquaria. Acta Oceanol. Sin., 29: 26-32 (2010).

Yasue, M., A. Nellas and A. C. J. Vincent. Seahorses helped drive creation of marine protected areas, so what did these protected areas do for the seahorses? Environ. Conserv., 39: 183-193 (2012).

Zhang, W., Y. Zhang, L. Zhang and Q. Lin. Bioaccumulation of Metals in Tissues of Seahorses Collected from Coastal China. Environ. Contam. Toxicol., 96: 281-288 (2016). 


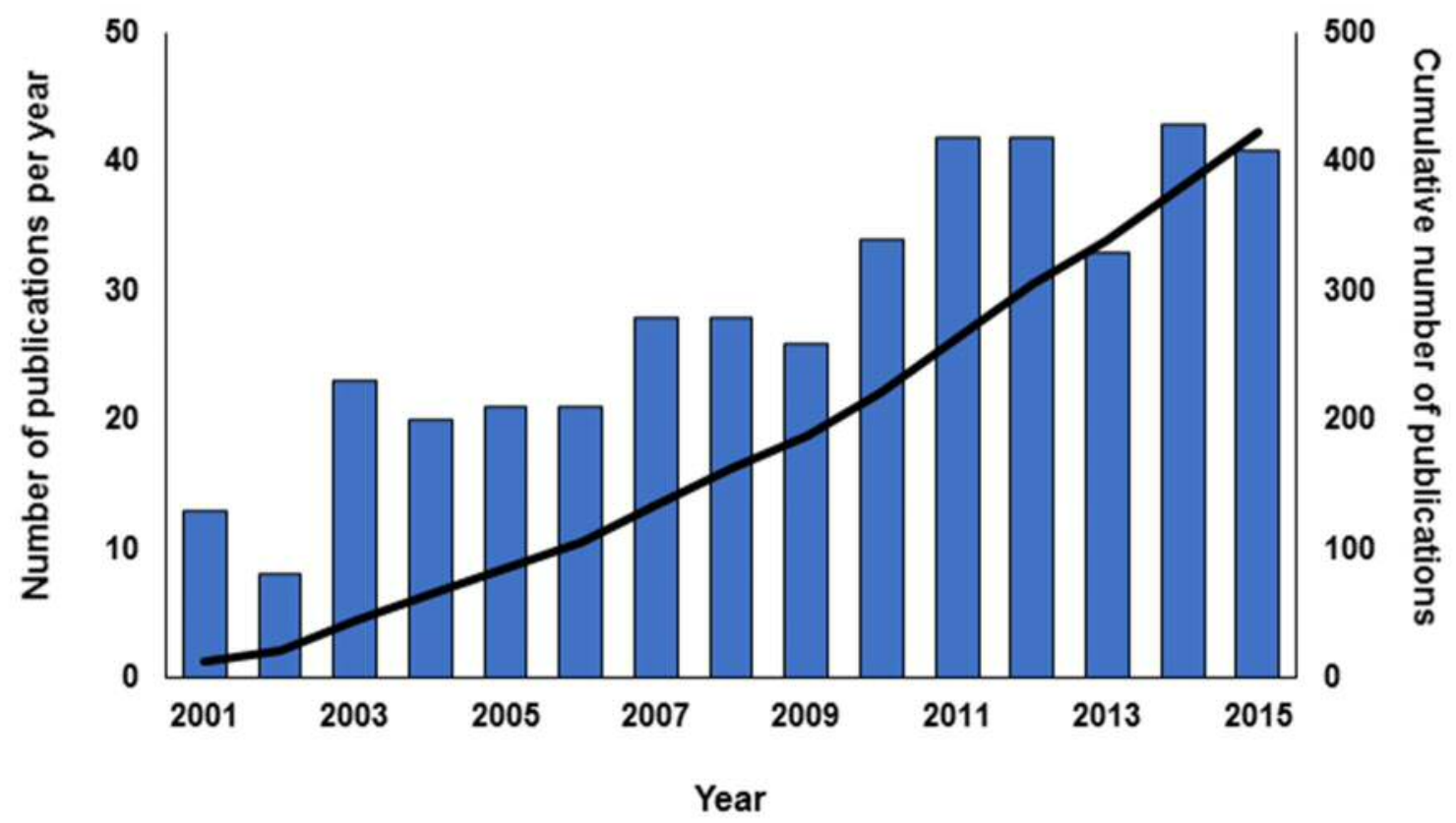

Figure 1. Number of scientific publications addressing seahorses retrieved from Thomson Reuters ${ }^{\mathrm{TM}}$ Web of Science ${ }^{\mathrm{TM}}$ (all databases) from 2001 to 2015. Bars show the number of publications per year and the line shows the cumulative number of publications. 


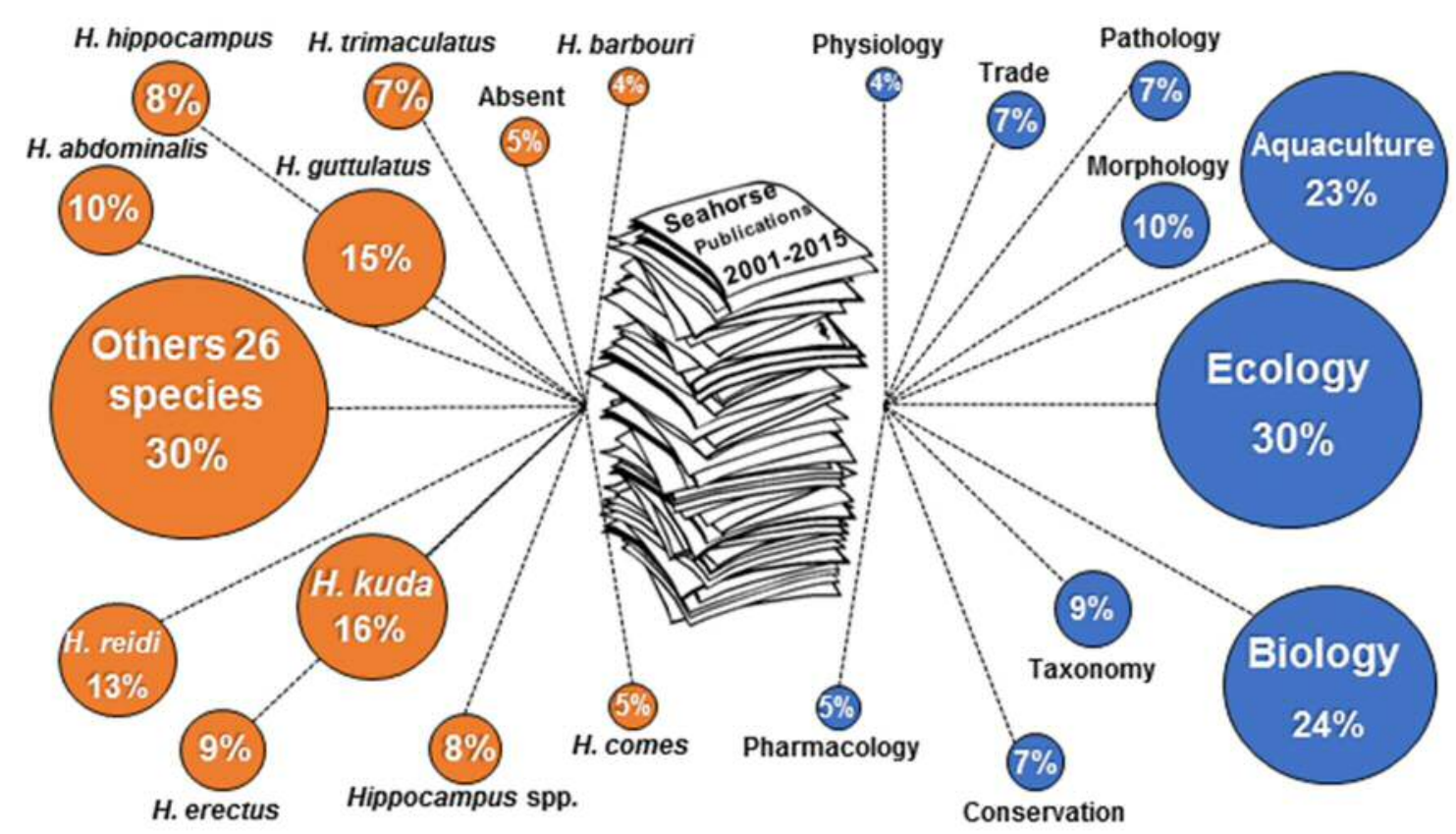

Figure 2. Percentage of scientific publications addressing each seahorse species (Orange left) and the most studied research fields (Blue - right) based on data retrieved from 423 scientific publications using Thomson Reuters ${ }^{\mathrm{TM}}$ Web of Science ${ }^{\mathrm{TM}}$ (all databases) from 2001 to 2015. Note: some publications addressed more than one species and/or field. 


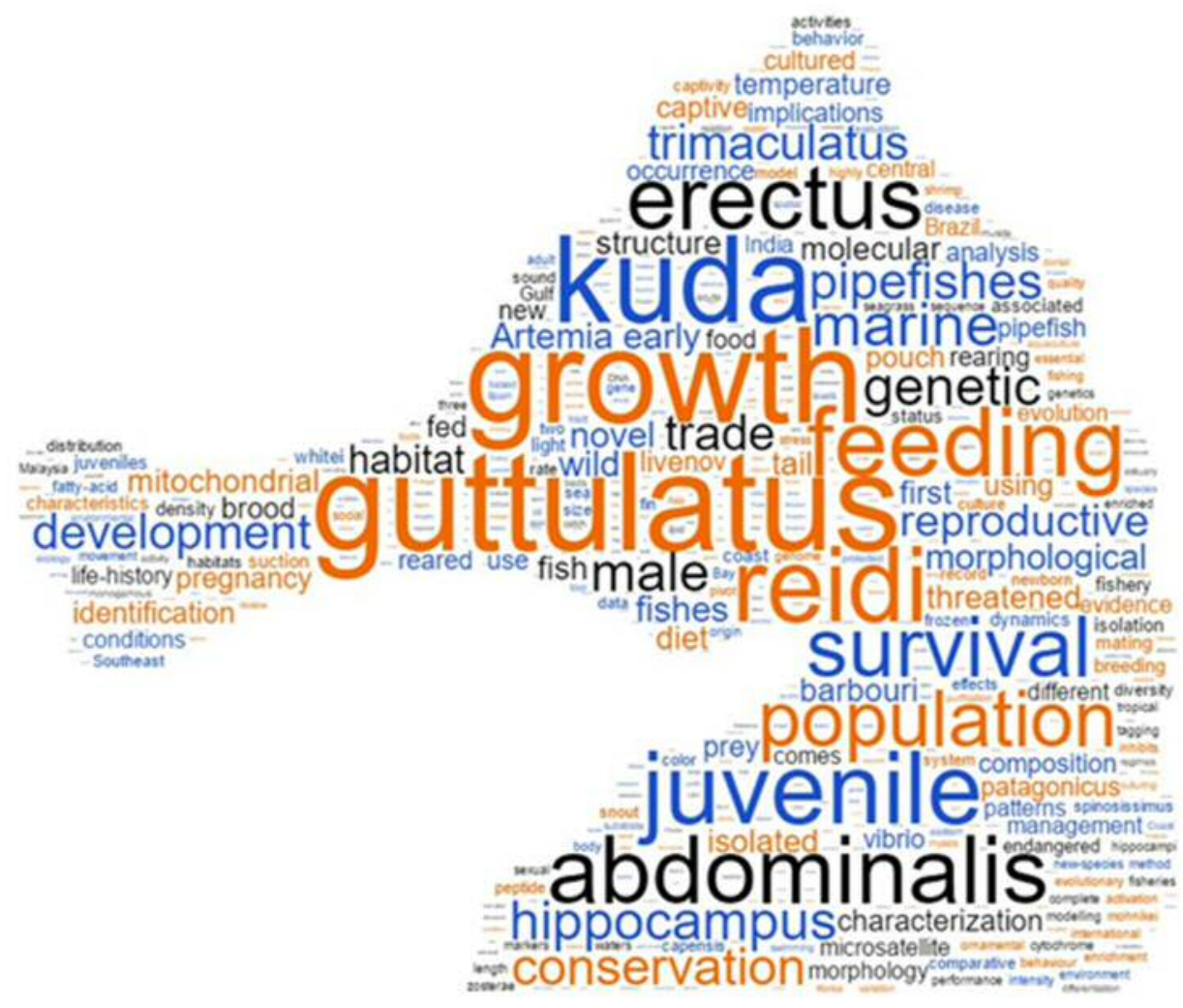

Figure 3. Wordcloud detailing the most common words featured in the titles of scientific publications addressing seahorses selected for this study retrieved from Thomson Reuters ${ }^{\mathrm{TM}}$ Web of Science ${ }^{\mathrm{TM}}$ (all databases) from 2001 to 2015. 


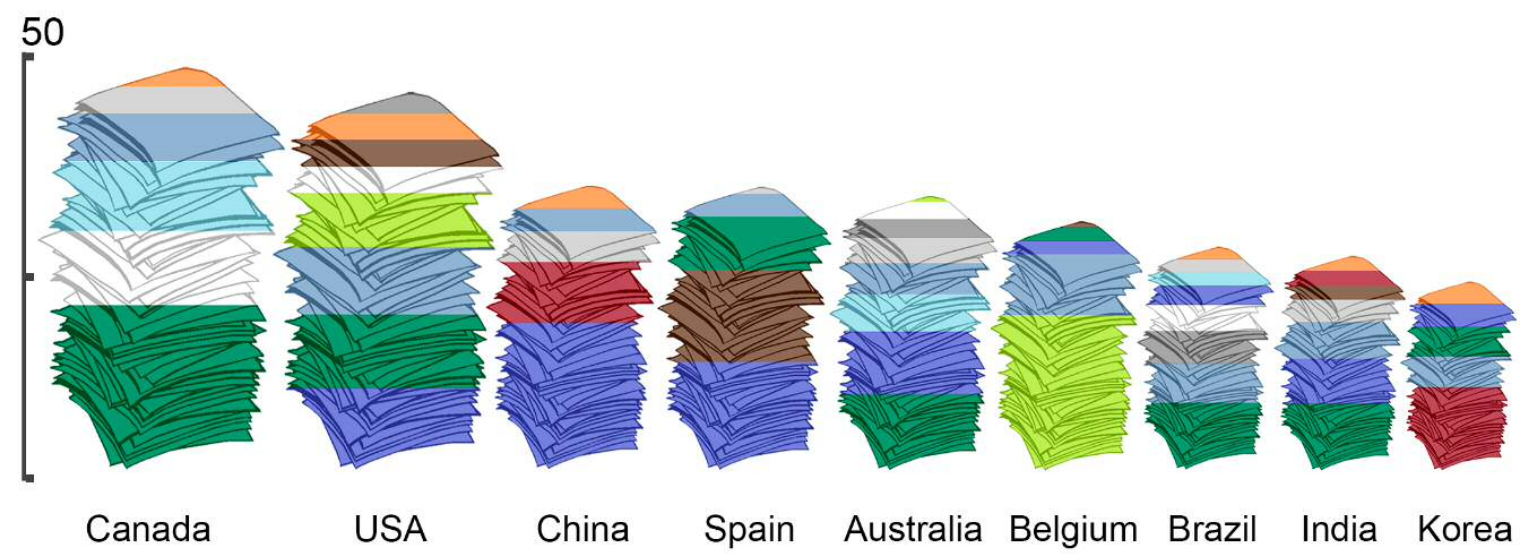

\begin{tabular}{|c|c|c|}
\hline Aquaculture & Ecology & Pathology \\
\hline Biology & Morphology & Pharmacology \\
\hline Conservation & Others & Physiology \\
\hline
\end{tabular}

Figure 4. Number of scientific publications addressing seahorses ranked by country and their main field of study based on data retrieved from Thomson Reuters ${ }^{\mathrm{TM}}$ Web of Science $^{\mathrm{TM}}$ (all databases) from 2001 to 2015. 


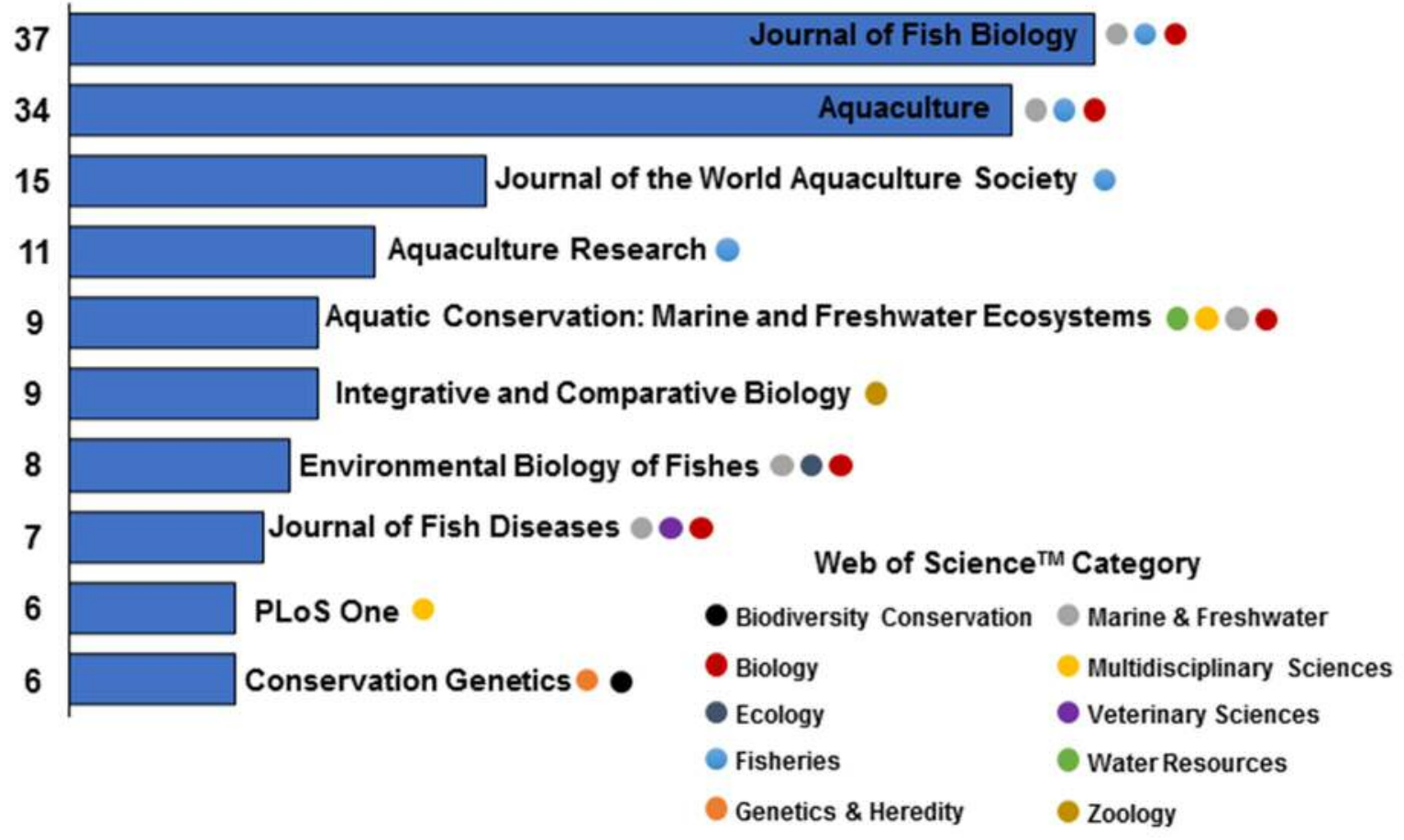

Figure 5. Top 10 scientific journals publishing scientific research on seahorses retrieved from Thomson Reuters ${ }^{\mathrm{TM}}$ Web of Science ${ }^{\mathrm{TM}}$ (all databases) from 2001 to 2015. 


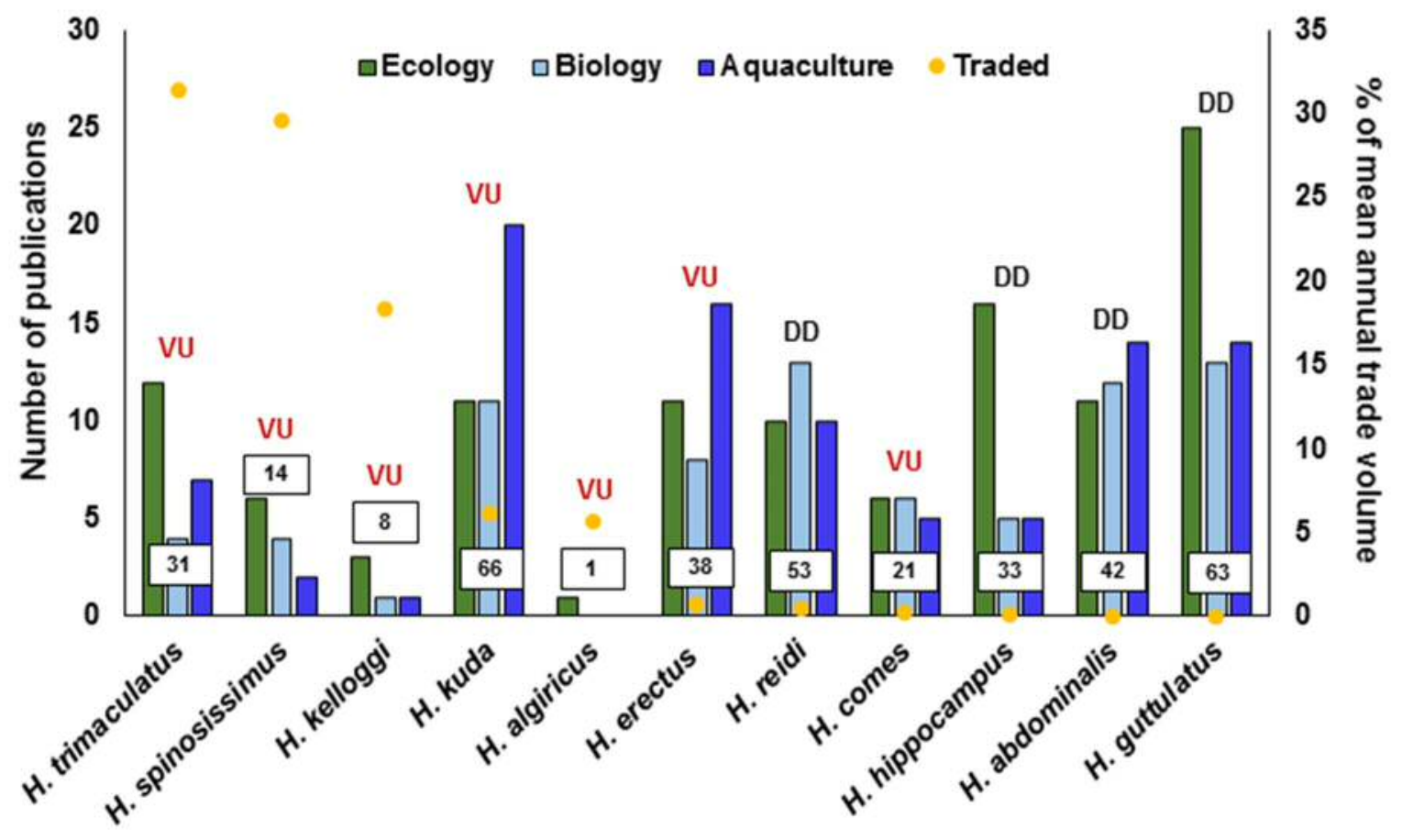

Figure 6. Number of scientific publications for the most studied and traded species of seahorses according to Thomson Reuters ${ }^{\mathrm{TM}}$ Web of Science ${ }^{\mathrm{TM}}$ (all databases) from 2001 to 2015. The risk of extinction for each species is indicated according to IUCN red list: VU = Vulnerable; and DD = Data Deficient. Total number of publication for each species - all studied fields included - is indicated in the boxes. Trade percentage was retrieved from Foster et al. (2016), which is an estimated mean of annual trade volume from CITES Trade Database (2004-2011). 
Table 1. Criteria employed to assign each reference addressing seahorses retrieved from Thomson Reuters ${ }^{\mathrm{TM}}$ Web of Science ${ }^{\mathrm{TM}}$ (all databases) from 2001 to 2015 to a given research field.

\section{Criteria}

Aquaculture

Biology

Conservation

Ecology

Morphology

Pathology

Pharmacology

Physiology

Taxonomy

Trade
Refers to the culture of seahorse in captivity.

Refers to behavior, growth, reproductive biology, and mating system of seahorses.

Refers to seahorse conservation.

Refers to population, habitats, distribution, migration, abundance, population dynamics, and natural diet.

Refers to the description and function of body parts, morphological development, muscles, and skeletons.

Refers to bacteria, virus, fungus or any other pathogen isolated from seahorses.

Refers to seahorse extract and compounds such as peptides, glycoproteins, and antioxidants.

Refers to seahorse metabolism, biochemistry, and general physiology, including studies of ecotoxicology.

Refers to species description and identification, including works with phylogeny.

Refers to the seahorse trade. 
Supplementary Table S1. All 423 references addressing seahorses retrieved from Thomson Reuters ${ }^{\mathrm{TM}}$ Web of Science ${ }^{\mathrm{TM}}$ (all databases) from 2001 to 2015 in March 2016.

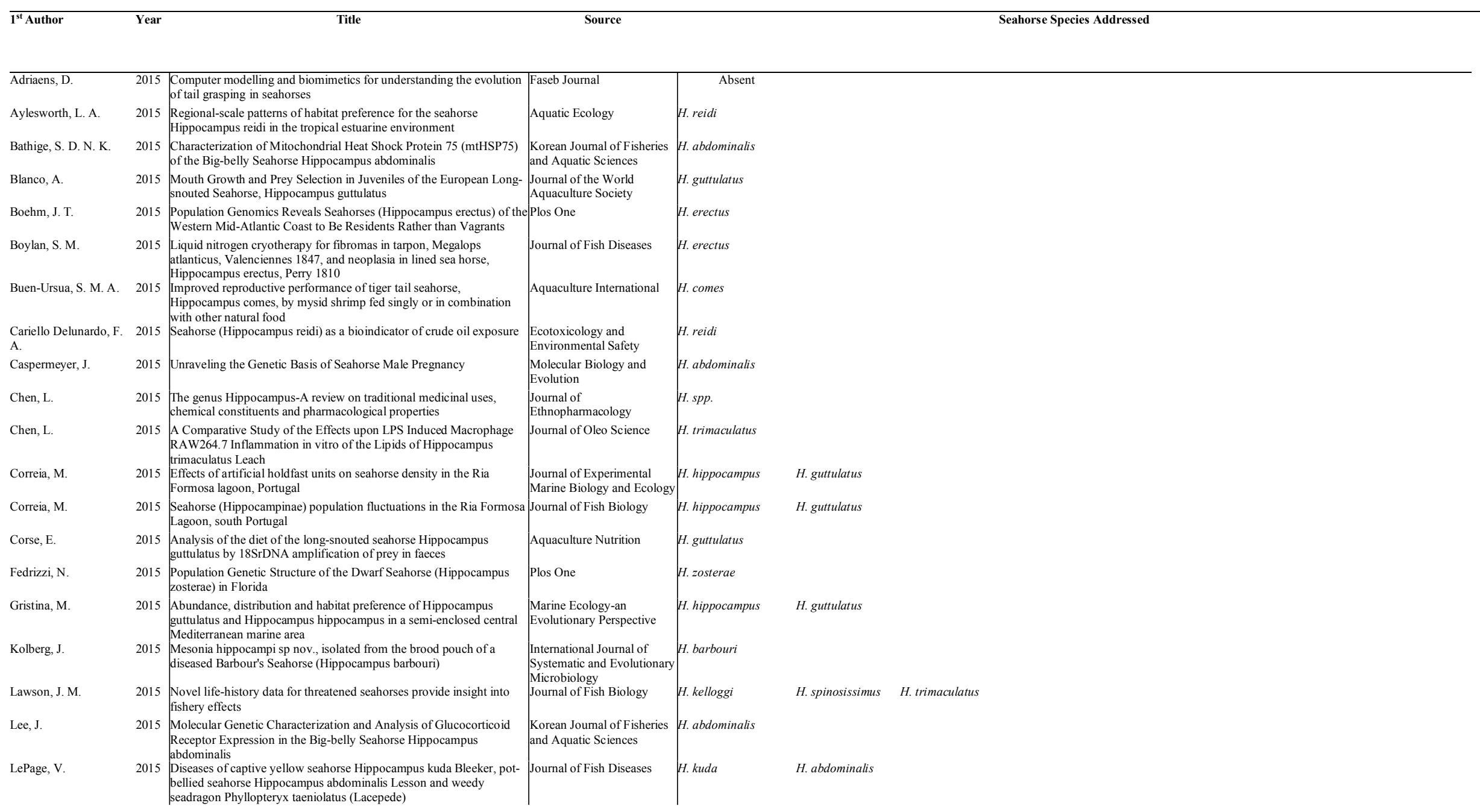




\begin{tabular}{|c|c|c|c|c|c|c|c|c|c|c|c|}
\hline Li, F. & 2015 & $\begin{array}{l}\text { Comparison of the Intestinal Bacterial Flora in Healthy and Intestinal- } \\
\text { diseased Seahorses Hippocampus trimaculatus, Hippocampus erectus, } \\
\text { and Hippocampus spinosissimus }\end{array}$ & \begin{tabular}{|l} 
Journal of the World \\
Aquaculture Society
\end{tabular} & H. erectus & H. spinosissimus & H. trimaculatus & & & & & \\
\hline Lim, A. C. O. & 2015 & $\begin{array}{l}\text { Sound production in the tiger-tail seahorse Hippocampus comes: } \\
\text { Insights into the sound producing mechanisms }\end{array}$ & $\begin{array}{l}\text { Journal of the Acoustical } \\
\text { Society of America }\end{array}$ & H. comes & & & & & & & \\
\hline Lopez, A. & 2015 & $\begin{array}{l}\text { Conservation Genetics of Threatened Hippocampus guttulatus in } \\
\text { Vulnerable Habitats in NW Spain: Temporal and Spatial Stability of } \\
\text { Wild Populations with Flexible Polygamous Mating System in } \\
\text { Captivity } \\
\text { A novel method for the identification of seahorses (genus } \\
\text { Hippocampus) using cross-species amplifiable microsatellites }\end{array}$ & Fisheries Research & H. guttulatus & H. mohnikei & H. trimaculatus & H. kelloggi & H. kuda & H. comes & H. barbouri & H. spinosissimus \\
\hline Novelli, B. & 2015 & $\begin{array}{l}\text { Development of seahorse (Hippocampus reidi, Ginsburg 1933): } \\
\text { histological and histochemical study }\end{array}$ & $\begin{array}{l}\text { Fish Physiology and } \\
\text { Biochemistry }\end{array}$ & H. reidi & & & & & & & \\
\hline Otero-Ferrer, F. & 2015 & $\begin{array}{l}\text { Spatial and seasonal patterns of European short-snouted seahorse } \\
\text { Hippocampus hippocampus distribution in island coastal environments }\end{array}$ & $\begin{array}{l}\text { African Journal of Marine } \\
\text { Science }\end{array}$ & H. hippocampus & & & & & & & \\
\hline Otero-Ferrer, F. & 2015 & $\begin{array}{l}\text { First records of Hippocampus algiricus in the Canary Islands (north- } \\
\text { east Atlantic Ocean) with an observation of hybridization with } \\
\text { Hippocampus hippocampus }\end{array}$ & Journal of Fish Biology & H. algiricus & H. hippocampus & & & & & & \\
\hline Park, J. M. & 2015 & $\begin{array}{l}\text { Length-weight relationships and reproductive characteristics of the } \\
\text { crowned seahorse (Hippocampus coronatus) in eelgrass beds (Zostera } \\
\text { marina) of Dongdae Bay, Korea }\end{array}$ & Marine Biology Research & H. coronatus & & & & & & & \\
\hline Porter, M. M. & 2015 & $\begin{array}{l}\text { Bioexploration: How engineering designs help elucidate the evolution } \\
\text { of seahorse tails }\end{array}$ & $\begin{array}{l}\text { Integrative and Comparative } \\
\text { Biology }\end{array}$ & Absent & & & & & & & \\
\hline Porter, M. M. & 2015 & Why the seahorse tail is square & Science & Absent & & & & & & & \\
\hline Segade, A. & 2015 & $\begin{array}{l}\text { Effects of the diet on seahorse (Hippocampus hippocampus) growth, } \\
\text { body colour and biochemical composition }\end{array}$ & Aquaculture Nutrition & H. hippocampus & & & & & & & \\
\hline $\mathrm{Su}, \mathrm{Y}$. & 2015 & $\begin{array}{l}\text { Study on the extraction and purification of glycoprotein from the } \\
\text { yellow seahorse, Hippocampus kuda Bleeker }\end{array}$ & Food Science \& Nutrition & H. kuda & & & & & & & \\
\hline Thuong, T. D. & 2015 & $\begin{array}{l}\text { Rearing the spotted seahorse Hippocampus kuda by feeding live and } \\
\text { frozen copepods collected from shrimp ponds }\end{array}$ & Aquaculture Research & H. kuda & & & & & & & \\
\hline Wang, B. & 2015 & $\begin{array}{l}\text { Complete mitochondrial genome sequence of the Barbour's seahorse } \\
\text { Hippocampus barbouri Jordan \& Richardson, } 1908 \\
\text { (Gasterosteiformes: Syngnathidae) }\end{array}$ & Mitochondrial DNA & H. barbouri & & & & & & & \\
\hline Whittington, C. M. & 2015 & $\begin{array}{l}\text { Seahorse Brood Pouch Transcriptome Reveals Common Genes } \\
\text { Associated with Vertebrate Pregnancy }\end{array}$ & $\begin{array}{l}\text { Molecular Biology and } \\
\text { Evolution }\end{array}$ & H. abdominalis & & & & & & & \\
\hline Woodall, L. C. & 2015 & $\begin{array}{l}\text { Past and present drivers of population structure in a small coastal fish, } \\
\text { the European long snouted seahorse Hippocampus guttulatus }\end{array}$ & Conservation Genetics & H. guttulatus & & & & & & & \\
\hline Yasue, M. & 2015 & Monitoring landed seahorse catch in a changing policy environment & $\begin{array}{l}\text { Endangered Species } \\
\text { Research }\end{array}$ & H. comes & & & & & & & \\
\hline Yip, M. Y. & 2015 & $\begin{array}{l}\text { Food and feeding habits of the seahorses Hippocampus spinosissimus } \\
\text { and Hippocampus trimaculatus (Malaysia) }\end{array}$ & $\begin{array}{l}\text { Journal of the Marine } \\
\text { Biological Association of the } \\
\text { United Kingdom }\end{array}$ & H. spinosissimus & H. trimaculatus & & & & & & \\
\hline Zhang, D. & 2015 & $\begin{array}{l}\text { A Comparison of Growth, Survival, and Fatty Acid Composition of } \\
\text { the Lined Seahorse, Hippocampus erectus, Juveniles Fed Enriched } \\
\text { Artemia and a Calanoid Copepod, Schmackeria dubia }\end{array}$ & $\begin{array}{l}\text { Journal of the World } \\
\text { Aquaculture Society }\end{array}$ & H. erectus & & & & & & & \\
\hline Zhang, Y. & 2015 & $\begin{array}{l}\text { Complete mitochondrial genome sequence of the lined seahorse } \\
\text { Hippocampus erectus Perry, } 1810 \text { (Gasterosteiformes: Syngnathidae) }\end{array}$ & Mitochondrial DNA & H. erectus & & & & & & & \\
\hline Zhang, Y. & 2015 & $\begin{array}{l}\text { Growth, Survivorship, Air-bubble Disease, and Attachment of Feeble } \\
\text { Juvenile Seahorses, Hippocampus kuda (Bleeker, 1852) }\end{array}$ & $\begin{array}{l}\text { Journal of the World } \\
\text { Aquaculture Society }\end{array}$ & H. kuda & & & & & & & \\
\hline Basusta, A. & 2014 & $\begin{array}{l}\text { Length-Weight Relationship and Condition Factor of Hippocampus } \\
\text { hippocampus and Hippocampus guttulatus Inhabiting Eastern Black } \\
\text { Sea }\end{array}$ & Pakistan Journal of Zoology & H. hippocampus & H. guttulatus & & & & & & \\
\hline Blanco, A. & 2014 & $\begin{array}{l}\text { Implications of physical key factors in the early rearing of the long- } \\
\text { snouted seahorse Hippocampus guttulatus }\end{array}$ & Aquaculture & H. guttulatus & & & & & & & \\
\hline Chakraborty, B. & 2014 & $\begin{array}{l}\text { Characterization of Yellow Seahorse Hippocampus kuda feeding click } \\
\text { sound signals in a laboratory environment: an application of } \\
\text { probability density function and power spectral density analyses }\end{array}$ & $\begin{array}{l}\text { Bioacoustics-the } \\
\text { International Journal of } \\
\text { Animal Sound and Its } \\
\text { Recording }\end{array}$ & H. kuda & & & & & & & \\
\hline
\end{tabular}




\begin{tabular}{|c|c|c|c|c|c|c|c|}
\hline Correia, M. & 2014 & $\begin{array}{l}\text { The use of a non-invasive tool for capture-recapture studies on a } \\
\text { seahorse Hippocampus guttulatus population }\end{array}$ & Journal of Fish Biology & H. guttulatus & & & \\
\hline Declercq, A. M. & 2014 & $\begin{array}{l}\text { White necrotic tail tips in estuary seahorses, Hippocampus kuda, } \\
\text { Bleeker }\end{array}$ & Journal of Fish Diseases & H. kuda & & & \\
\hline Edelstein, L. W. & 2014 & $\begin{array}{l}\text { An evo-devo study of evolutionary novelties: the origin of the seahorse } \\
\text { tail }\end{array}$ & $\begin{array}{l}\text { Integrative and Comparative } \\
\text { Biology }\end{array}$ & H. zosterae & & & \\
\hline Franz-Odendaal, T. A. & 2014 & $\begin{array}{l}\text { Comparative developmental osteology of the seahorse skeleton reveals } \\
\text { heterochrony amongst Hippocampus sp and progressive caudal fin loss }\end{array}$ & EvoDevo & H. reidi & H. subelongatus & H. zosterae & \\
\hline Gonzalez, R. & 2014 & $\begin{array}{l}\text { Genetic evidence and new morphometric data as essential tools to } \\
\text { identify the Patagonian seahorse Hippocampus patagonicus (Pisces, } \\
\text { Syngnathidae) }\end{array}$ & Journal of Fish Biology & H. patagonicus & & & \\
\hline Gonzalez, R. & 2014 & $\begin{array}{l}\text { Reply to Luzzatto et al. (2014): "Comment on 'Genetic evidence and } \\
\text { new morphometric data as essential tools to identify the Patagonian } \\
\text { seahorse Hippocampus patagonicus (Pisces, Syngnathidae), Gonzalez } \\
\text { et al. (2014)"' }\end{array}$ & Journal of Fish Biology & H. patagonicus & & & \\
\hline Harasti, D. & 2014 & Does a No-Take Marine Protected Area Benefit Seahorses? & Plos One & H. whitei & & & \\
\hline Harasti, D. & 2014 & $\begin{array}{l}\text { Ontogenetic and sex-based differences in habitat preferences and site } \\
\text { fidelity of White's seahorse Hippocampus whitei }\end{array}$ & Journal of Fish Biology & H. whitei & & & \\
\hline Haris, $\mathrm{K}$. & 2014 & $\begin{array}{l}\text { Multifractal detrended fluctuation analysis to characterize phase } \\
\text { couplings in seahorse (Hippocampus kuda) feeding clicks }\end{array}$ & $\begin{array}{l}\text { Journal of the Acoustical } \\
\text { Society of America }\end{array}$ & H. kuda & & & \\
\hline Jiang, $\mathrm{Z}$. & 2014 & $\begin{array}{l}\text { Preparation process of active enzymolysis polypeptides from seahorse } \\
\text { bone meal }\end{array}$ & Food science \& nutrition & H. trimaculatus & & & \\
\hline Kasapoglu, Nazli & 2014 & $\begin{array}{l}\text { Some Population Characteristics of Long-snouted Seahorse } \\
\text { (Hippocampus guttulatus Cuvier, 1829) (Actinopterygii: } \\
\text { Syngnathidae) in the Southeastern Black Sea }\end{array}$ & Acta Zoologica Bulgarica & H. guttulatus & & & \\
\hline Luis Balcazar, J. & 2014 & $\begin{array}{l}\text { Mycobacterium hippocampi sp nov, a Rapidly Growing } \\
\text { Scotochromogenic Species Isolated from a Seahorse with Tail Rot }\end{array}$ & Current Microbiology & H. guttulatus & & & \\
\hline Luzzatto, D. C. & 2014 & $\begin{array}{l}\text { Comment on 'Genetic evidence and new morphometric data as } \\
\text { essential tools to identify the Patagonian seahorse Hippocampus } \\
\text { patagonicus (Pisces, Syngnathidae) by Gonzalez et al. (2014)' }\end{array}$ & Journal of Fish Biology & H. patagonicus & & & \\
\hline Nenciu, M. I. & 2014 & $\begin{array}{l}\text { Pollutant bioaccumulation in the Long-Snouted Seahorse at the } \\
\text { Romanian Coast }\end{array}$ & $\begin{array}{l}\text { Journal of Environmental } \\
\text { Protection and Ecology }\end{array}$ & H. guttulatus & & & \\
\hline Neutens, C. & 2014 & Grasping convergent evolution in syngnathids: a unique tale of tails & Journal of Anatomy & H. reidi & H. capensis & H. abdominalis & H. breviceps \\
\hline Ofelio, C. & 2014 & $\begin{array}{l}\text { Isolation and molecular identification of the scuticociliate Porpostoma } \\
\text { notata Moebius, } 1888 \text { from moribund reared Hippocampus } \\
\text { hippocampus (L.) seahorses, by amplification of the SSU rRNA gene } \\
\text { sequences }\end{array}$ & Journal of Fish Diseases & H. hippocampus & & & \\
\hline Oliveira, T.P. R. & 2014 & $\begin{array}{l}\text { Sounds produced by the longsnout seahorse: a study of their structure } \\
\text { and functions }\end{array}$ & Journal of Zoology & H. reidi & & & \\
\hline Otero-Ferrer, F. & 2014 & $\begin{array}{l}\text { Embryonic developmental plasticity in the long-snouted seahorse } \\
\text { (Hippocampus reidi, Ginsburg 1933) in relation to parental } \\
\text { preconception diet }\end{array}$ & $\begin{array}{l}\text { Reproduction, fertility, and } \\
\text { development }\end{array}$ & H. reidi & & & \\
\hline Palma, J. & 2014 & $\begin{array}{l}\text { The effect of diet on ontogenic development of the digestive tract in } \\
\text { juvenile reared long snout seahorse Hippocampus guttulatus }\end{array}$ & $\begin{array}{l}\text { Fish Physiology and } \\
\text { Biochemistry }\end{array}$ & H. guttulatus & & & \\
\hline Praet, T. & 2014 & $\begin{array}{l}\text { Understanding the mechanics of tail grasping in seahorses using a } \\
\text { parametrized computer model }\end{array}$ & $\begin{array}{l}\text { Integrative and Comparative } \\
\text { Biology }\end{array}$ & Absent & & & \\
\hline Qin, G. & 2014 & $\begin{array}{l}\text { Effects of water current on swimming performance, ventilation } \\
\text { frequency, and feeding behavior of young seahorses (Hippocampus } \\
\text { erectus) }\end{array}$ & \begin{tabular}{|l|} 
Journal of Experimental \\
Marine Biology and Ecology
\end{tabular} & H. erectus & & & \\
\hline Rose, E. & 2014 & $\begin{array}{l}\text { Genetic Evidence for Monogamy in the Dwarf Seahorse, } \\
\text { Hippocampus zosterae }\end{array}$ & Journal of Heredity & H. zosterae & & & \\
\hline Saavedra, M. & 2014 & $\begin{array}{l}\text { Dietary fatty acid enrichment increases egg size and quality of yellow } \\
\text { seahorse Hippocampus kuda }\end{array}$ & $\begin{array}{l}\text { Animal Reproduction } \\
\text { Science }\end{array}$ & H. kuda & & & \\
\hline Sanaye, S. V. & 2014 & $\begin{array}{l}\text { Evaluation of antioxidant activities in captive-bred cultured yellow } \\
\text { seahorse, Hippocampus kuda (Bleeker, 1852) }\end{array}$ & Aquaculture & H. kuda & & & \\
\hline
\end{tabular}




\begin{tabular}{|c|c|c|c|c|c|c|}
\hline $\begin{array}{l}\text { Sánchez-Cardozo, L. } \\
\text { M. }\end{array}$ & 2014 & $\begin{array}{l}\text { Efecto de la dieta en el crecimiento y supervivencia de crías de } \\
\text { caballito de mar Hippocampus reidi em condicionaes de laboratorio }\end{array}$ & $\begin{array}{l}\text { Boletin de Investigaciones } \\
\text { Marinas y Costeras - } \\
\text { INVEMAR }\end{array}$ & H. reidi & & \\
\hline Shin, S. Y. & 2014 & $\begin{array}{l}\text { Seahorse-derived peptide suppresses invasive migration of HT1080 } \\
\text { fibrosarcoma cells by competing with intracellular } \alpha \text {-enolase for } \\
\text { plasminogen binding and inhibiting uPA-mediated activation of } \\
\text { plasminogen }\end{array}$ & BMB Reports & H. kuda & & \\
\hline Silveira, R. B. & 2014 & $\begin{array}{l}\text { Morphological and molecular evidence for the occurrence of three } \\
\text { Hippocampus species (Teleostei: Syngnathidae) in Brazil }\end{array}$ & Zootaxa & H. erectus & H. patagonicus & H. reidi \\
\hline Song, $\mathrm{H}$. & 2014 & $\begin{array}{l}\text { Complete mitochondrial genome sequence of the thorny seahorse } \\
\text { Hippocampus histrix (Gasterosteiformes: Syngnathidae }\end{array}$ & Mitochondrial DNA & H. histrix & & \\
\hline Song, H. Y. & 2014 & $\begin{array}{l}\text { Mitogenomic circumscription of a novel percomorph fish clade mainly } \\
\text { comprising "Syngnathoidei" (Teleostei) }\end{array}$ & Gene & H. kuda & & \\
\hline Subburaman, $\mathrm{S}$. & 2014 & $\begin{array}{l}\text { First distributional record of the giraffe seahorse, Hippocampus } \\
\text { camelopardalis Bianconi } 1854 \text { (Family: Syngnathidae) from Gulf of } \\
\text { Kachchh waters, North west coast of India }\end{array}$ & $\begin{array}{l}\text { Indian Journal of Geo- } \\
\text { Marine Sciences }\end{array}$ & H. camelopardalis & & \\
\hline Tiralongo, $\mathrm{F}$. & 2014 & $\begin{array}{l}\text { A conspicuous population of the Long-Snouted seahorse, } \\
\text { Hippocampus guttulatus (ACTINOPTER YGII: } \\
\text { SYNGNATHIFORMES SYNGNATHIDAE), in a highly pollut } \\
\text { mediterranean Coastal Lagoon }\end{array}$ & $\begin{array}{l}\text { Acta Ichthyologica Et } \\
\text { Piscatoria }\end{array}$ & H. guttulatus & & \\
\hline Valladares, $\mathrm{S}$. & 2014 & $\begin{array}{l}\text { First records of the seahorse Hippocampus hippocampus in Galician } \\
\text { waters (NW Spain) }\end{array}$ & Cybium & H. hippocampus & & \\
\hline Van Wassenbergh, S. & 2014 & New Insights into Muscle Function during Pivot Feeding in Seahorses & Plos One & H. kuda & H. reidi & \\
\hline Vieira, R. P. & 2014 & $\begin{array}{l}\text { Length-weight relationships of six syngnathid species from Ria } \\
\text { Formosa, SW Iberian coast }\end{array}$ & Cahiers De Biologie Marine & H. hippocampus & H. guttulatus & \\
\hline Vincent, A. C. J. & 2014 & $\begin{array}{l}\text { The role of CITES in the conservation of marine fishes subject to } \\
\text { international trade }\end{array}$ & Fish and Fisheries & H. spp. & & \\
\hline Vite-Garcia, N. & 2014 & $\begin{array}{l}\text { Growth and survival of Hippocampus erectus (Perry, 1810) juveniles } \\
\text { fed on Artemia with different HUFA levels }\end{array}$ & $\begin{array}{l}\text { Latin American Journal of } \\
\text { Aquatic Research }\end{array}$ & H. erectus & & \\
\hline Vite-Garcia, N. & 2014 & $\begin{array}{l}\text { Assessment of lipid classes and fatty acid levels in wild newborn } \\
\text { seahorses (Hippocampus erectus) (Perry 1810): implications for } \\
\text { survival and growth in aquarium culture }\end{array}$ & $\begin{array}{l}\text { Marine and Freshwater } \\
\text { Behaviour and Physiology }\end{array}$ & H. erectus & & \\
\hline Williams, S. L. & 2014 & $\begin{array}{l}\text { Ornamental Marine Species Culture in the Coral Triangle: Seahorse } \\
\text { Demonstration Project in the Spermonde Islands, Sulawesi, Indonesia }\end{array}$ & Environmental Management & H. barbouri & & \\
\hline $\mathrm{Xu}$, Dong-Hui & 2014 & $\begin{array}{l}\text { Protective effects of seahorse extracts in a rat castration and } \\
\text { testosterone-induced benign prostatic hyperplasia model and mouse } \\
\text { oligospermatism model }\end{array}$ & $\begin{array}{l}\text { Environmental Toxicology } \\
\text { and Pharmacology }\end{array}$ & H. trimaculatus & H. kuda & \\
\hline Zhang, Y. & 2014 & $\begin{array}{l}\text { Genetic Variations in Two Seahorse Species (Hippocampus mohnikei } \\
\text { and Hippocampus trimaculatus): Evidence for Middle Pleistocene } \\
\text { Population Expansion }\end{array}$ & Plos One & H. trimaculatus & H. mohnikei & \\
\hline Anderson, P. A. & 2013 & $\begin{array}{l}\text { Mixed Metazoan and Bacterial Infection of the Gas Bladder of the } \\
\text { Lined Seahorse-A Case Report }\end{array}$ & $\begin{array}{l}\text { Journal of Aquatic Animal } \\
\text { Health }\end{array}$ & H. erectus & & \\
\hline Anderson, P. A. & 2013 & $\begin{array}{l}\text { Acoustic characterization of seahorse tank environments in public } \\
\text { aquaria: A citizen science project }\end{array}$ & Aquacultural Engineering & H. spp. & & \\
\hline Aurelio, M. & 2013 & $\begin{array}{l}\text { Physiological and behavioral responses of temperate seahorses } \\
\text { (Hippocampus guttulatus) to environmental warming }\end{array}$ & Marine Biology & H. guttulatus & & \\
\hline Boehm, J. T. & 2013 & Marine dispersal and barriers drive Atlantic seahorse diversification & Journal of Biogeography & H. erectus & H. patagonicus & H. hippocampus \\
\hline Caldwell, I. R. & 2013 & $\begin{array}{l}\text { A sedentary fish on the move: effects of displacement on long-snouted } \\
\text { seahorse (Hippocampus guttulatus Cuvier) movement and habitat use }\end{array}$ & $\begin{array}{l}\text { Environmental Biology of } \\
\text { Fishes }\end{array}$ & H. guttulatus & & \\
\hline $\begin{array}{l}\text { Cariello Delunardo, F. } \\
\text { A. }\end{array}$ & 2013 & $\begin{array}{l}\text { Genotoxic and morphological damage in Hippocampus reidi exposed } \\
\text { to crude oil }\end{array}$ & $\begin{array}{l}\text { Ecotoxicology and } \\
\text { Environmental Safety }\end{array}$ & H. reidi & & \\
\hline Chang, Chia-Hao & 2013 & $\begin{array}{l}\text { The complete mitochondrial genome of the tiger tail seahorse, } \\
\text { Hippocampus comes (Teleostei, Syngnathidae) }\end{array}$ & Mitochondrial DNA & H. comes & & \\
\hline Correia, Miguel & 2013 & $\begin{array}{l}\text { Can artificial holdfast units work as a habitat restoration tool for long- } \\
\text { snouted seahorse (Hippocampus guttulatus Cuvier)? }\end{array}$ & $\left|\begin{array}{l}\text { Journal of Experimental } \\
\text { Marine Biology and Ecology }\end{array}\right|$ & H. guttulatus & & \\
\hline
\end{tabular}




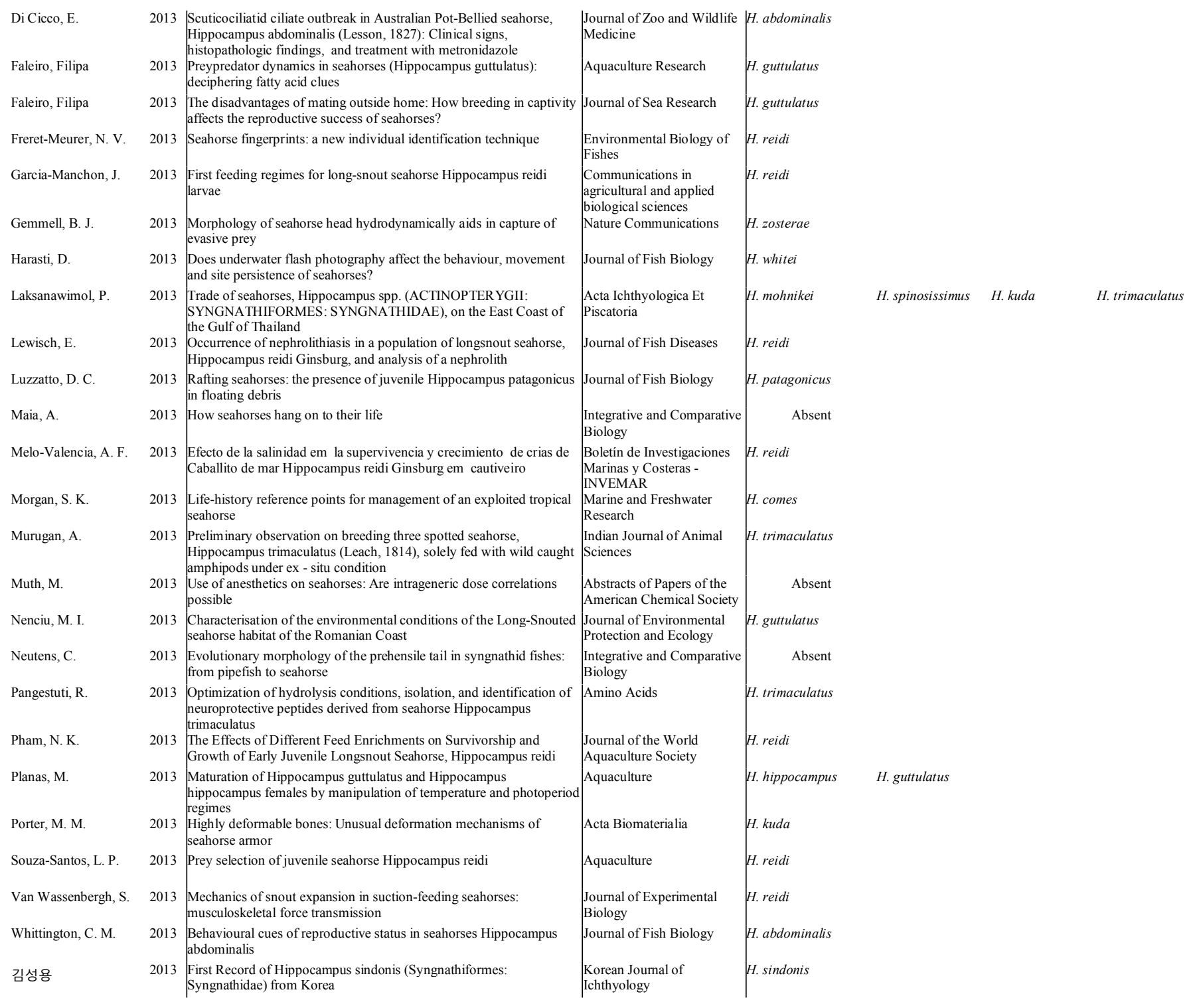




\begin{tabular}{|c|c|c|c|c|c|}
\hline Anderson, P. A. & 2012 & $\begin{array}{l}\text { Sexual Dimorphism in Morphometry and Allometry of the Adult } \\
\text { Lined Seahorse, Hippocampus erectus }\end{array}$ & Copeia & H. erectus & \\
\hline Bahr, A. & 2012 & $\begin{array}{l}\text { Mutual mate choice in the potbellied seahorse (Hippocampus } \\
\text { abdominalis) }\end{array}$ & Behavioral Ecology & H. abdominalis & \\
\hline Blanco, A. & 2012 & $\begin{array}{l}\text { First observations of conjoined twins in newborn seahorses, } \\
\text { Hippocampus guttulatus Cuvier }\end{array}$ & Journal of Fish Diseases & H. guttulatus & \\
\hline Caldwell, I. R. & 2012 & $\begin{array}{l}\text { Revisiting two sympatric European seahorse species: apparent decline } \\
\text { in the absence of exploitation }\end{array}$ & $\begin{array}{l}\text { Aquatic Conservation- } \\
\text { Marine and Freshwater } \\
\text { Ecosystems }\end{array}$ & H. guttulatus & H. hippocampus \\
\hline Celino, F. T. & 2012 & $\begin{array}{l}\text { Feeding selectivity of the seahorse, Hippocampus kuda (Bleeker), } \\
\text { juveniles under laboratory conditions }\end{array}$ & Aquaculture Research & H. kuda & \\
\hline Choi, Young-Ung & 2012 & $\begin{array}{l}\text { Population characteristics of two seahorses, Hippocampus coronatus } \\
\text { and Hippocampus mohnikei, around seagrass beds in the southern } \\
\text { coastal waters of Korea }\end{array}$ & Ichthyological Research & H. coronatus & H. mohnikei \\
\hline Freret-Meurer, N. V. & 2012 & $\begin{array}{l}\text { Activity rate of the seahorse Hippocampus reidi Ginsburg, } 1933 \\
\text { (Syngnathidae) }\end{array}$ & Acta Ethologica & H. reidi & \\
\hline Garcia, Luis Maria B. & 2012 & $\begin{array}{l}\text { Diet composition and feeding periodicity of the seahorse Hippocampus } \\
\text { barbouri reared in illuminated sea cages }\end{array}$ & is Aquaculture & H. barbouri & \\
\hline Harasti, D. & 2012 & $\begin{array}{l}\text { Population dynamics and life history of a geographically restricted } \\
\text { seahorse, Hippocampus whitei }\end{array}$ & Journal of Fish Biology & H. whitei & \\
\hline Himaya, S. W. A. & 2012 & $\begin{array}{l}\text { Paeonol from Hippocampus kuda Bleeler suppressed the neuro- } \\
\text { inflammatory responses in vitro via NF-kappa B and MAPK signaling } \\
\text { pathways }\end{array}$ & Toxicology in Vitro & H. kuda & \\
\hline Kayis, $\mathrm{S}$. & 2012 & $\begin{array}{l}\text { Nerocila bivittata (Cymothidae, Isopoda) infestation on Syngnathid } \\
\text { Fishes in the Eastern Black Sea }\end{array}$ & $\begin{array}{l}\text { Bulletin of the European } \\
\text { Association of Fish } \\
\text { Pathologists }\end{array}$ & H. guttulatus & \\
\hline Kumaravel, K. & 2012 & Seahorses - A source of traditional medicine & Natural Product Research & H. spp. & \\
\hline Kwon, K. S. & 2012 & $\begin{array}{l}\text { An Anti-inflammatory Peptide Isolated from Seahorse Hippocampus } \\
\text { kuda bleeler Inhibits the Invasive Potential of MG-63 Osteosarcoma } \\
\text { Cell }\end{array}$ & $\begin{array}{l}\text { Fisheries and Aquatic } \\
\text { Sciences }\end{array}$ & H. kuda & \\
\hline Lin, Q. & 2012 & $\begin{array}{l}\text { The dynamics of reproductive rate, offspring survivorship and growth } \\
\text { in the lined seahorse, Hippocampus erectus Perry, } 1810\end{array}$ & Biology Open & H. erectus & \\
\hline Lopez, A. & 2012 & $\begin{array}{l}\text { A microsatellite panel for mating system analysis and broodstock } \\
\text { management of captive long-snouted seahorse Hippocampus guttulatus }\end{array}$ & Aquaculture & H. guttulatus & \\
\hline Luis Balcazar, J. & 2012 & $\begin{array}{l}\text { Oceanibacterium hippocampi gen. nov., sp. nov., isolated from } \\
\text { cutaneous mucus of wild seahorses (Hippocampus guttulatus) }\end{array}$ & $\begin{array}{l}\text { Antonie Van Leeuwenhoek } \\
\text { International Journal of } \\
\text { General and Molecular } \\
\text { Microbiology }\end{array}$ & H. guttulatus & \\
\hline Luis Balcazar, J. & 2012 & $\begin{array}{l}\text { Vibrio inhibens sp nov., a novel bacterium with inhibitory activity } \\
\text { against Vibrio species }\end{array}$ & Journal of Antibiotics & H. guttulatus & \\
\hline Luzzatto, D. C. & 2012 & $\begin{array}{l}\text { The presence of the seahorse Hippocampus patagonicus in the } \\
\text { Argentine Sea based on the cytochrome b sequence of mitochondrial } \\
\text { DNA }\end{array}$ & Cybium & H. patagonicus & \\
\hline Martinez-Cardenas, L. & 2012 & $\begin{array}{l}\text { Substrate-attachment Preferences of Cultured Newborn Pot-bellied } \\
\text { Seahorses, Hippocampus abdominalis (Lesson, 1827) }\end{array}$ & $\begin{array}{l}\text { Journal of the World } \\
\text { Aquaculture Society }\end{array}$ & H. abdominalis & \\
\hline Martinez-Cardenas, L. & 2012 & $\begin{array}{l}\text { Effect of stocking density and photoperiod on growth and survival in } \\
\text { cultured early juvenile pot-bellied seahorses Hippocampus } \\
\text { abdominalis Lesson, } 1827\end{array}$ & Aquaculture Research & H. abdominalis & \\
\hline Nickel, J. & 2012 & $\begin{array}{l}\text { Genetic diversity and population structure of the pot-belly seahorse } \\
\text { Hippocampus abdominalis in New Zealand }\end{array}$ & $\begin{array}{l}\text { New Zealand Journal of } \\
\text { Marine and Freshwater } \\
\text { Research }\end{array}$ & H. abdominalis & \\
\hline O'Donnell, Kerrie P. & 2012 & $\begin{array}{l}\text { Comparing Fisher Interviews, Logbooks, and Catch Landings } \\
\text { Estimates of Extraction Rates in a Small-Scale Fishery }\end{array}$ & Coastal Management & H. comes & \\
\hline Otero-Ferrer, F. & 2012 & $\begin{array}{l}\text { Effect of Different Live Prey on Spawning Quality of Short-Snouted } \\
\text { Seahorse, Hippocampus hippocampus (Linnaeus, 1758) }\end{array}$ & $\begin{array}{l}\text { Journal of the World } \\
\text { Aquaculture Society }\end{array}$ & H. hippocampus & \\
\hline Palma, J. & 2012 & $\begin{array}{l}\text { Growth, Reproductive Performances, and Brood Quality of Long } \\
\text { Snout Seahorse, Hippocampus guttulatus, Fed Enriched Shrimp Diets }\end{array}$ & $\begin{array}{l}\text { Journal of the World } \\
\text { Aquaculture Society }\end{array}$ & H. guttulatus & \\
\hline
\end{tabular}




\begin{tabular}{|c|c|c|c|c|c|}
\hline Planas, M. & 2012 & $\begin{array}{l}\text { Temperature-induced changes of growth and survival in the early } \\
\text { development of the seahorse Hippocampus guttulatus }\end{array}$ & $\begin{array}{l}\text { Journal of Experimental } \\
\text { Marine Biology and Ecology }\end{array}$ & H. guttulatus & \\
\hline Praet, T. & 2012 & $\begin{array}{l}\text { Inspiration from nature: dynamic modelling of the musculoskeletal } \\
\text { structure of the seahorse tail }\end{array}$ & $\begin{array}{l}\text { International Journal for } \\
\text { Numerical Methods in } \\
\text { Biomedical Engineering }\end{array}$ & H. reidi & \\
\hline Qian, Zhong-Ji & 2012 & $\begin{array}{l}\text { Isolation and antioxidant activity evaluation of two new phthalate } \\
\text { derivatives from seahorse, Hippocampus Kuda Bleeler }\end{array}$ & $\begin{array}{l}\text { Biotechnology and } \\
\text { Bioprocess Engineering }\end{array}$ & H. kuda & \\
\hline Qin, Geng & 2012 & $\begin{array}{l}\text { Effect of broodstock origin, background and substrate color on skin } \\
\text { coloration of three-spotted seahorses Hippocampus trimaculatus } \\
\text { Leach, } 1814\end{array}$ & $\begin{array}{l}\text { Journal of Experimental } \\
\text { Marine Biology and Ecology }\end{array}$ & H. trimaculatus & \\
\hline Roth, $\mathrm{O}$. & 2012 & Male Pregnancy and Biparental Immune Priming & American Naturalist & Absent & \\
\hline Salter, C. E. & 2012 & $\begin{array}{l}\text { Dermatitis and systemic mycosis in lined seahorses Hippocampus } \\
\text { erectus associated with a marine-adapted Fusarium solani species } \\
\text { complex pathogen }\end{array}$ & $\begin{array}{l}\text { Diseases of Aquatic } \\
\text { Organisms }\end{array}$ & H. erectus & \\
\hline Singh, K. V. & 2012 & $\begin{array}{l}\text { Microsatellite loci to determine population structure in the yellow } \\
\text { seahorse (Hippocampus kuda) and the three-spotted seahorse (H. } \\
\text { trimaculatus) }\end{array}$ & Marine Biodiversity & H. kuda & H. trimaculatus \\
\hline Smith, R. E. & 2012 & $\begin{array}{l}\text { Extreme habitat specialisation and population structure of two } \\
\text { gorgonian-associated pygmy seahorses }\end{array}$ & $\begin{array}{l}\text { Marine Ecology Progress } \\
\text { Series }\end{array}$ & H. bargibanti & H. denise \\
\hline Sommer, S. & 2012 & $\begin{array}{l}\text { Standardised classification of pre-release development in male- } \\
\text { brooding pipefish, seahorses, and seadragons (Family Syngnathidae) }\end{array}$ & Bmc Developmental Biology & H. abdominalis & \\
\hline Tanu & 2012 & $\begin{array}{l}\text { A study on bacteria associated with the intestinal tract of farmed } \\
\text { yellow seahorse, Hippocampus kuda (Bleeker, 1852): characterization } \\
\text { and extracellular enzymes }\end{array}$ & Aquaculture Research & H. kuda & \\
\hline Uncumusaoglu, A. A. & 2012 & $\begin{array}{l}\text { A preliminary research on heavy metals accumulated in liver and } \\
\text { muscle tissue of seahorse (Hippocampus hippocampus) catched from } \\
\text { Tirebolu Coasts (Giresun, Eastern Black ea) }\end{array}$ & $\begin{array}{l}\text { Fresenius Environmental } \\
\text { Bulletin }\end{array}$ & H. hipросатриs & \\
\hline Valladares, $\mathrm{S}$. & 2012 & Non-lethal dorsal fin sampling for stable isotope analysis in seahorses & Aquatic Ecology & H. guttulatus & \\
\hline Van Wassenbergh, S. & 2012 & $\begin{array}{l}\text { Three-dimensional model of force transmission in the suction feeding } \\
\text { system of seahorses }\end{array}$ & $\begin{array}{l}\text { Integrative and Comparative } \\
\text { Biology }\end{array}$ & Absent & \\
\hline Willadino, L. & 2012 & $\begin{array}{l}\text { Ingestion rate, survival and growth of newly released seahorse } \\
\text { Hippocampus reidi fed exclusively on cultured live food items }\end{array}$ & Aquaculture & H. reidi & \\
\hline Woodall, L. C. & 2012 & $\begin{array}{l}\text { Partial fin-clipping as an effective tool for tissue sampling seahorses, } \\
\text { Hippocampus spp }\end{array}$ & $\begin{array}{l}\text { Journal of the Marine } \\
\text { Biological Association of the } \\
\text { United Kingdom }\end{array}$ & H. kuda & \\
\hline Yasue, M. & 2012 & $\begin{array}{l}\text { Seahorses helped drive creation of marine protected areas, so what did } \\
\text { these protected areas do for the seahorses? }\end{array}$ & Environmental Conservation & H. spp. & \\
\hline Yin, $F$. & 2012 & $\begin{array}{l}\text { Lipid Metabolic Response, Peroxidation, and Antioxidant Defence } \\
\text { Status of Juvenile Lined Seahorse, Hippocampus erectus, Fed with } \\
\text { Highly Unsaturated Fatty Acids Enriched Artemia Nauplii }\end{array}$ & $\begin{array}{l}\text { Journal of the World } \\
\text { Aquaculture Society }\end{array}$ & H. erectus & \\
\hline Zheng, L. & 2012 & $\begin{array}{l}\text { Rapid finding and quantification of the major antioxidant in water } \\
\text { extracts of three marine drug organisms from China by online HPLC- } \\
\text { DAD/MS-DPPH }\end{array}$ & Natural Product Research & H. japonicus & H. kuda \\
\hline Ahnesjo, I. & 2011 & The biology of Syngnathidae: pipefishes, seadragons and seahorses & Journal of Fish Biology & H. spp. & \\
\hline Anderson, P. A. & 2011 & $\begin{array}{l}\text { Evoked potential audiogram of the lined seahorse, Hippocampus } \\
\text { erectus (Perry), in terms of sound pressure and particle acceleration }\end{array}$ & $\begin{array}{l}\text { Environmental Biology of } \\
\text { Fishes }\end{array}$ & H. erectus & \\
\hline Anderson, P. A. & 2011 & $\begin{array}{l}\text { Sound, stress, and seahorses: The consequences of a noisy } \\
\text { environment to animal health }\end{array}$ & Aquaculture & H. erectus & \\
\hline Bahr, A. & 2011 & $\begin{array}{l}\text { The impact of sex-role reversal on the diversity of the major } \\
\text { histocompatibility complex: Insights from the seahorse (Hippocampus } \\
\text { abdominalis) }\end{array}$ & Bmc Evolutionary Biology & H. abdominalis & \\
\hline Buen-Ursua, S. M. A. & 2011 & $\begin{array}{l}\text { Effects of UV-Treated Sea Water, Chlorinated Sea Water, and } \\
\text { Formalin-Treated Copepods on Survival and Growth of Newborn } \\
\text { Seahorses, Hippocampus comes }\end{array}$ & $\begin{array}{l}\text { Israeli Journal of } \\
\text { Aquaculture-Bamidgeh }\end{array}$ & H. comes & \\
\hline Caldwell, I. R. & 2011 & $\begin{array}{l}\text { Advances in tagging syngnathids, with the effects of dummy tags on } \\
\text { behaviour of Hippocampus guttulatus }\end{array}$ & Journal of Fish Biology & H. guttulatus & \\
\hline
\end{tabular}




\begin{tabular}{|c|c|c|c|c|c|c|}
\hline Cunha, M. A. & 2011 & $\begin{array}{l}\text { Anesthetic induction and recovery of Hippocampus reidi exposed to } \\
\text { the essential oil of Lippia alba }\end{array}$ & Neotropical Ichthyology & H. reidi & & \\
\hline Gurkan, S. & 2011 & $\begin{array}{l}\text { Gut Contents of Two European Seahorses Hippocampus hippocampus } \\
\text { and Hippocampus guttulatus in the Aegean Sea, Coasts of Turkey }\end{array}$ & Pakistan Journal of Zoology & H. hippocampus & H. guttulatus & \\
\hline Hellyer, C. B. & 2011 & $\begin{array}{l}\text { Manipulating artificial habitats to benefit seahorses in Sydney } \\
\text { Harbour, Australia }\end{array}$ & $\begin{array}{l}\text { Aquatic Conservation- } \\
\text { Marine and Freshwater } \\
\text { Ecosystems }\end{array}$ & H. whitei & & \\
\hline Jawad, L. & 2011 & $\begin{array}{l}\text { On the occurrence of the Egyptian seahorse Hippocampus suezensis } \\
\text { Duncker, } 1940 \text { in Muscat, Sultanate of Oman }\end{array}$ & Acta Adriatica & H. suezensis & & \\
\hline Kayis, S. & 2011 & $\begin{array}{l}\text { Ascidian Tunicate, Botryllus schlosseri (Pallas, 1766) infestation on } \\
\text { Seahorse }\end{array}$ & $\begin{array}{l}\text { Bulletin of the European } \\
\text { Association of Fish } \\
\text { Pathologists }\end{array}$ & H. guttulatus & & \\
\hline Kleiber, D. & 2011 & $\begin{array}{l}\text { The importance of seahorses and pipefishes in the diet of marine } \\
\text { animals }\end{array}$ & $\begin{array}{l}\text { Reviews in Fish Biology and } \\
\text { Fisheries }\end{array}$ & H. spp. & & \\
\hline Krishnan, T. S. & 2011 & $\begin{array}{l}\text { Occurrence of western Indian Ocean seahorse Hippocampus } \\
\text { borboniensis Dumeril, 1870, in the Gulf of Mannars, Southeastern } \\
\text { India }\end{array}$ & $\begin{array}{l}\text { Indian Journal of Geo- } \\
\text { Marine Sciences }\end{array}$ & H. borboniensis & & \\
\hline Lee, H. R. & 2011 & $\begin{array}{l}\text { Morphological and behavioral limit of visual resolution in temperate } \\
\text { (Hippocampus abdominalis) and tropical (Hippocampus taeniopterus) } \\
\text { seahorses }\end{array}$ & Visual Neuroscience & H. abdominalis & H. taeniopterus & \\
\hline Leysen, $\mathrm{H}$. & 2011 & $\begin{array}{l}\text { Morphological Variation in Head Shape of Pipefishes and Seahorses in } \\
\text { Relation to Snout Length and Developmental Growth }\end{array}$ & Journal of Morphology & H. reidi & & \\
\hline Leysen, H. & 2011 & $\begin{array}{l}\text { Modelling stress in the feeding apparatus of seahorses and pipefishes } \\
\text { (Teleostei: Syngnathidae) }\end{array}$ & $\begin{array}{l}\text { Biological Journal of the } \\
\text { Linnean Society }\end{array}$ & H. abdominalis & H. reidi & H. zosterae \\
\hline Leysen, H. & 2011 & $\begin{array}{l}\text { Musculoskeletal structure of the feeding system and implications of } \\
\text { snout elongation in Hippocampus reidi and Dunckerocampus } \\
\text { dactyliophorus }\end{array}$ & Journal of Fish Biology & H. reidi & & \\
\hline Lim, A. C. O. & 2011 & $\begin{array}{l}\text { Diversity, habitats and conservation threats of syngnathid } \\
\text { (Syngnathidae) fishes in Malaysia }\end{array}$ & Tropical Zoology & H. spp. & & \\
\hline Luis Balcazar, J. & 2011 & Novel Mycobacterium Species in Seahorses with Tail Rot & $\begin{array}{l}\text { Emerging Infectious } \\
\text { Diseases }\end{array}$ & H. hippocampus & H. guttulatus & \\
\hline Martinez-Cardenas, L. & 2011 & $\begin{array}{l}\text { Effect of Temperature on Growth and Survival in Cultured Early } \\
\text { Juvenile Pot-bellied Seahorses, Hippocampus abdominalis }\end{array}$ & $\begin{array}{l}\text { Journal of the World } \\
\text { Aquaculture Society }\end{array}$ & H. abdominalis & & \\
\hline Mobley, K. B. & 2011 & $\begin{array}{l}\text { The genetics and genomics of Syngnathidae: pipefishes, seahorses and } \\
\text { seadragons }\end{array}$ & Journal of Fish Biology & Absent & & \\
\hline Murugan, A. & 2011 & $\begin{array}{l}\text { Fishery biology, demography of three spotted seahorse, Hippocampus } \\
\text { trimaculatus inhabiting Gulf of Mannar region, Southeast coast of } \\
\text { India }\end{array}$ & $\begin{array}{l}\text { Indian Journal of Geo- } \\
\text { Marine Sciences }\end{array}$ & H. trimaculatus & & \\
\hline Negreiros, L. A. & 2011 & $\begin{array}{l}\text { Effects of hypoxia and petroleum on the genotoxic and morphological } \\
\text { parameters of Hippocampus reidi }\end{array}$ & $\begin{array}{l}\text { Comparative Biochemistry } \\
\text { and Physiology C- } \\
\text { Toxicology \& Pharmacology }\end{array}$ & H. reidi & & \\
\hline Olivotto, I. & 2011 & Advances in Breeding and Rearing Marine Ornamentals & $\begin{array}{l}\text { Toxicology \& Pharmacology } \\
\text { Journal of the World } \\
\text { Aquaculture Society }\end{array}$ & H. spp. & & \\
\hline Palma, Jorge & 2011 & $\begin{array}{l}\text { Effect of different Artemia enrichments and feeding protocol for } \\
\text { rearing juvenile long snout seahorse, Hippocampus guttulatus }\end{array}$ & Aquaculture & H. guttulatus & & \\
\hline Pawar, H. B. & 2011 & $\begin{array}{l}\text { Effect of Background Color of Tanks on Growth and Survival of } \\
\text { Juvenile Yellow Seahorse, Hippocampus kuda (Bleeker 1852), in the } \\
\text { Pelagic Phase }\end{array}$ & $\begin{array}{l}\text { Israeli Journal of } \\
\text { Aquaculture-Bamidgeh }\end{array}$ & H. kuda & & \\
\hline Pawar, H. R. & 2011 & $\begin{array}{l}\text { Comparative efficacy of four anaesthetic agents in the yellow } \\
\text { seahorse, Hippocampus kuda (Bleeker, 1852) }\end{array}$ & Aquaculture & H. kuda & & \\
\hline Reijnen, B. T. & 2011 & Fish, fans and hydroids: host species of pygmy seahorses & Zookeys & H. bargibanti & H. denise & H. pontohi \\
\hline Roos, G. & 2011 & $\begin{array}{l}\text { Effects of snout dimensions on the hydrodynamics of suction feeding } \\
\text { in juvenile and adult seahorses }\end{array}$ & $\begin{array}{l}\text { Journal of Theoretical } \\
\text { Biology }\end{array}$ & H. reidi & & \\
\hline Rosa, I. L. & 2011 & $\begin{array}{l}\text { Fisheries and trade of seahorses in Brazil: historical perspective, } \\
\text { current trends, and future directions }\end{array}$ & $\begin{array}{l}\text { Biodiversity and } \\
\text { Conservation }\end{array}$ & H. reidi & H. erectus & \\
\hline Rosenqvist, G. & 2011 & Sexual signals and mating patterns in Syngnathidae & Journal of Fish Biology & H. spp. & & \\
\hline
\end{tabular}




\begin{tabular}{|c|c|c|c|c|c|c|}
\hline Sears, B. F. & 2011 & $\begin{array}{l}\text { A new species of Myxosporean (SPHAEROMYXIDAE), a parasite of } \\
\text { lined seahorses, Hippocampus erectus, from the Gulf of Mexico }\end{array}$ & Journal of Parasitology & H. erectus & & \\
\hline Shin, S. P. & 2011 & $\begin{array}{l}\text { Identification of scuticociliate Philasterides dicentrarchi from indo- } \\
\text { pacific seahorses Hippocampus kuda }\end{array}$ & $\begin{array}{l}\text { African Journal of } \\
\text { Microbiology Research }\end{array}$ & H. kuda & & \\
\hline Singh, K. V. & 2011 & $\begin{array}{l}\text { Molecular identification and phylogenetic relationship of seahorse, } \\
\text { Hippocampus kuda (Bleeker } 1852 \text { ) using mitochondrial } 16 \mathrm{~S} \text { rRNA and } \\
\text { COI gene sequences from east and west coasts of India }\end{array}$ & $\begin{array}{l}\text { Indian Journal of Animal } \\
\text { Sciences }\end{array}$ & H. kuda & & \\
\hline Szabo, Z. & 2011 & $\begin{array}{l}\text { On the status of the Hawaiian seahorses Hippocampus hilonis, } \mathrm{H} \text {. } \\
\text { histrix and H. fisheri (Syngnathidae) }\end{array}$ & Marine Biology Research & H. hilonis & H. histrix & H. fisheri \\
\hline Thangaraj, M. & 2011 & $\begin{array}{l}\text { Assessment of genetic variation in closely related seahorse species } \\
\text { (Genus: Hippocampus) using mtDNA marker }\end{array}$ & $\begin{array}{l}\text { Indian Journal of } \\
\text { Biotechnology }\end{array}$ & H. kuda & H. trimaculatus & \\
\hline Van Wassenbergh, S. & 2011 & An adaptive explanation for the horse-like shape of seahorses & Nature Communications & H. reidi & H. breviceps & H. abdominalis \\
\hline Vincent, A. C. J. & 2011 & Conservation and management of seahorses and other Syngnathidae & Journal of Fish Biology & H. spp. & & \\
\hline Wilson, A. B. & 2011 & The evolutionary origins of Syngnathidae: pipefishes and seahorses & Journal of Fish Biology & H. spp. & & \\
\hline Woodall, L. C. & 2011 & $\begin{array}{l}\text { Historical and contemporary population genetic connectivity of the } \\
\text { European short-snouted seahorse Hippocampus hippocampus and } \\
\text { implications for management }\end{array}$ & Journal of Fish Biology & H. hippocampus & & \\
\hline Woodall, L. C. & 2011 & $\begin{array}{l}\text { Serial monogamy in the European long-snouted seahorse } \\
\text { Hippocampus guttulatus }\end{array}$ & Conservation Genetics & H. guttulatus & & \\
\hline Zhang, D. & 2011 & $\begin{array}{l}\text { Criteria for assessing juvenile quality of the lined seahorse, } \\
\text { Hippocampus erectus }\end{array}$ & Aquaculture & H. erectus & & \\
\hline Ahnesjo, I. & 2010 & Seahorses and their relatives & Journal of Fish Biology & H. spp. & & \\
\hline Balcazar, J. L. & 2010 & $\begin{array}{l}\text { Identification and characterization of bacteria with antibacterial } \\
\text { activities isolated from seahorses (Hippocampus guttulatus) }\end{array}$ & Journal of Antibiotics & H. guttulatus & & \\
\hline Balcazar, J. L. & 2010 & $\begin{array}{l}\text { Phylogenetic characterization and in situ detection of bacterial } \\
\text { communities associated with seahorses (Hippocampus guttulatus) in } \\
\text { captivity }\end{array}$ & $\begin{array}{l}\text { Systematic and Applied } \\
\text { Microbiology }\end{array}$ & H. guttulatus & & \\
\hline Balcazar, J. L. & 2010 & $\begin{array}{l}\text { Isolation of Vibrio alginolyticus and Vibrio splendidus from captive- } \\
\text { bred seahorses with disease symptoms }\end{array}$ & $\begin{array}{l}\text { Antonie Van Leeuwenhoek } \\
\text { International Journal of } \\
\text { General and Molecular } \\
\text { Microbiology }\end{array}$ & H. hippocampus & H. guttulatus & \\
\hline Faleiro, F. & 2010 & $\begin{array}{l}\text { Lipid dynamics during early development of Hippocampus guttulatus } \\
\text { seahorses: Searching for clues on fatty acid requirements }\end{array}$ & Aquaculture & H. guttulatus & & \\
\hline Foster, R. & 2010 & $\begin{array}{l}\text { A new seahorse (Teleostei: Syngnathidae: Hippocampus) from south- } \\
\text { western Australia }\end{array}$ & Zootaxa & H. paradoxus & & \\
\hline Garcia, L. M. B. & 2010 & $\begin{array}{l}\text { Culturing Seahorse (Hippocampus barbouri) in Illuminated Cages with } \\
\text { Supplementary Acetes Feeding }\end{array}$ & $\begin{array}{l}\text { Israeli Journal of } \\
\text { Aquaculture-Bamidgeh }\end{array}$ & H. barbouri & & \\
\hline Harasti, D. & 2010 & $\begin{array}{l}\text { Striking a balance between retaining populations of protected } \\
\text { seahorses and maintaining swimming nets }\end{array}$ & $\begin{array}{l}\text { Aquatic Conservation- } \\
\text { Marine and Freshwater } \\
\text { Ecosystems }\end{array}$ & H. abdominalis & H. whitei & \\
\hline Koldewey, H. J. & 2010 & A global review of seahorse aquaculture & Aquaculture & H. spp. & & \\
\hline Leysen, H. & 2010 & $\begin{array}{l}\text { Cranial Architecture of Tube-Snouted Gasterosteiformes (Syngnathus } \\
\text { rostellatus and Hippocampus capensis) }\end{array}$ & Journal of Morphology & H. capensis & & \\
\hline Lin, Q. & 2010 & $\begin{array}{l}\text { Effects of light intensity, stocking density and temperature on the air- } \\
\text { bubble disease, survivorship and growth of early juvenile seahorse } \\
\text { Hippocampus erectus Perry, } 1810\end{array}$ & Aquaculture Research & H. erectus & & \\
\hline Lopez, A. & 2010 & $\begin{array}{l}\text { Species identification and genetic structure of threatened seahorses in } \\
\text { Gran Canaria Island (Spain) using mitochondrial and microsatellite } \\
\text { markers }\end{array}$ & Conservation Genetics & H. hippocampus & H. guttulatus & \\
\hline Luis Balcazar, J. & 2010 & $\begin{array}{l}\text { Bacillus galliciensis sp nov., isolated from faeces of wild seahorses } \\
\text { (Hippocampus guttulatus) }\end{array}$ & $\begin{array}{l}\text { International Journal of } \\
\text { Systematic and Evolutionary } \\
\text { Microbiology }\end{array}$ & H. guttulatus & & \\
\hline Luis Balcazar, J. & 2010 & $\mid$\begin{tabular}{|l} 
Vibrio hippocampi sp nov., a new species isolated from wild seahorses \\
(Hippocampus guttulatus)
\end{tabular} & Fems Microbiology Letters & H. guttulatus & & \\
\hline
\end{tabular}




\begin{tabular}{|c|c|c|c|c|}
\hline Martins, M. L. & 2010 & $\begin{array}{l}\text { Isolation and experimental infection with Vibrio alginolyticus in the } \\
\text { sea horse, Hippocampus reidi Ginsburg, } 1933 \text { (Osteichthyes: } \\
\text { Syngnathidae) in Brazil } \\
\text { An examination of the population dynamics of syngnathid fishes } \\
\text { within Tampa Bay, Florida, USA }\end{array}$ & Brazilian Journal of Biology & H. zosterae \\
\hline Nijman, Vincent & 2010 & An overview of international wildlife trade from Southeast Asia & $\begin{array}{l}\text { Biodiversity and } \\
\text { Conservation }\end{array}$ & H. spp. \\
\hline O'Donnell, K. P. & 2010 & $\begin{array}{l}\text { How does the accuracy of fisher knowledge affect seahorse } \\
\text { conservation status? }\end{array}$ & Animal Conservation & H. comes \\
\hline Oliveira, T. P. R. & 2010 & $\begin{array}{l}\text { Novel sex-related characteristics of the longsnout seahorse } \\
\text { Hippocampus reidi Ginsburg, } 1933\end{array}$ & Neotropical Ichthyology & H. reidi \\
\hline Otero-Ferrer, $\mathrm{F}$. & 2010 & $\begin{array}{l}\text { Live prey first feeding regimes for short-snouted seahorse } \\
\text { Hippocampus hippocampus (Linnaeus, 1758) juveniles }\end{array}$ & Aquaculture Research & H. hippoca \\
\hline Panithanarak, $\mathrm{T}$. & 2010 & $\begin{array}{l}\text { Population Genetics of the Spotted Seahorse (Hippocampus kuda) in } \\
\text { Thai Waters: Implications for Conservation }\end{array}$ & Zoological Studies & H. kuda \\
\hline Perry, A. L. & 2010 & $\begin{array}{l}\text { Fisheries, large-scale trade, and conservation of seahorses in Malaysia } \\
\text { and Thailand }\end{array}$ & $\begin{array}{l}\text { Aquatic Conservation- } \\
\text { Marine and Freshwater } \\
\text { Ecosystems }\end{array}$ & H. barbouri \\
\hline Planas, M. & 2010 & $\begin{array}{l}\text { Female maturation, egg characteristics and fatty acids profile in the } \\
\text { seahorse Hippocampus guttulatus }\end{array}$ & $\begin{array}{l}\text { Animal Reproduction } \\
\text { Science }\end{array}$ & H. guttulatus \\
\hline Raj, S. T. & 2010 & $\begin{array}{l}\text { Characterization and infectivity evaluation of Vibrio harveyi causing } \\
\text { white patch disease among captive reared seahorses, hippocampus } \\
\text { kuda }\end{array}$ & $\begin{array}{l}\text { Indian Journal of Marine } \\
\text { Sciences }\end{array}$ & H. kuda \\
\hline Roos, G. & 2010 & $\begin{array}{l}\text { Snout allometry in seahorses: insights on optimisation of pivot feeding } \\
\text { performance during ontogeny }\end{array}$ & $\begin{array}{l}\text { Journal of Experimental } \\
\text { Biology }\end{array}$ & H. reidi \\
\hline Ryu, BoMi & 2010 & $\begin{array}{l}\text { SHP-1, a novel peptide isolated from seahorse inhibits collagen release } \\
\text { through the suppression of collagenases } 1 \text { and } 3 \text {, nitric oxide products } \\
\text { regulated by NF-kappa B/p38 kinase }\end{array}$ & Peptides & H. kuda \\
\hline Ryu, BoMi & 2010 & $\begin{array}{l}\text { Purification of a peptide from seahorse, that inhibits TPA-induced } \\
\text { MMP, iNOS and COX-2 expression through MAPK and NF-kappa B } \\
\text { activation, and induces human osteoblastic and chondrocytic } \\
\text { differentiation }\end{array}$ & $\begin{array}{l}\text { Chemico-Biological } \\
\text { Interactions }\end{array}$ & H. kuda \\
\hline Saarman, N. P. & 2010 & $\begin{array}{l}\text { Genetic differentiation across eastern Pacific oceanographic barriers in } \\
\text { the threatened seahorse Hippocampus ingens }\end{array}$ & Conservation Genetics & H. ingens \\
\hline Santos, C. A. & 2010 & $\begin{array}{l}\text { Genotoxic effects of the diesel water-soluble fraction on the seahorse } \\
\text { Hippocampus reidi (Teleostei: Syngnathidae) during acute exposure }\end{array}$ & Zoologia & H. reidi \\
\hline Scales, H. & 2010 & $\begin{array}{l}\text { Advances in the ecology, biogeography and conservation of seahorses } \\
\text { (genus Hippocampus) }\end{array}$ & $\begin{array}{l}\text { Progress in Physical } \\
\text { Geography }\end{array}$ & H. spp. \\
\hline Tindemans, $\mathrm{D}$. & 2010 & $\begin{array}{l}\text { Development of the digestive tract in the seahorse (Hippocampus } \\
\text { erectus P.) }\end{array}$ & $\begin{array}{l}\text { Vlaams Diergeneeskundig } \\
\text { Tijdschrift }\end{array}$ & H. erectus \\
\hline Van Wassenbergh, S. & 2010 & The head-down posture of seahorses: an adaptation for pivot feeding? & $\begin{array}{l}\text { Integrative and Comparative } \\
\text { Biology }\end{array}$ & \\
\hline $\mathrm{Xu}, \mathrm{Y}$. & 2010 & $\begin{array}{l}\text { Polyculture of the lined seahorse, Hippocampus erectus Perry, } 1810 \\
\text { with two species of macroalgae in aquaria }\end{array}$ & Acta Oceanologica Sinica & H. erectus \\
\hline Zhang, D & 2010 & $\begin{array}{l}\text { Growth and survival of juvenile lined seahorse, Hippocampus erectus } \\
\text { (Perry), at different stocking densities }\end{array}$ & Aquaculture Research & H. erectus \\
\hline Garcia, L. M. B. & 2009 & $\begin{array}{l}\text { Grow-out of juvenile seahorse Hippocampus kuda (Bleeker, Teleostei: } \\
\text { Syngnathidae) in illuminated sea cages }\end{array}$ & Aquaculture Research & H. kuda \\
\hline Goswami, M. & 2009 & $\begin{array}{l}\text { Genetic heterogeneity in the Indian stocks of seahorse (Hippocampus } \\
\text { kuda and Hippocampus trimaculatus) inferred from mtDNA } \\
\text { cytochrome b gene }\end{array}$ & Hydrobiologia & H. kuda \\
\hline Hora, M. S. C. & 2009 & $\begin{array}{l}\text { Closing the reproductive cycle: Growth of the seahorse Hippocampus } \\
\text { reidi (Teleostei, Syngnathidae) from birth to adulthood under } \\
\text { experimental conditions }\end{array}$ & Aquaculture & H. reidi \\
\hline Leysen, H. & 2009 & $\begin{array}{l}\text { Stress distribution and morphological specializations in the feeding } \\
\text { apparatus of a seahorse (Syngnathidae: Hippocampus reidi) }\end{array}$ & $\begin{array}{l}\text { Integrative and Com } \\
\text { Biology }\end{array}$ & H. reidi \\
\hline Lin, Q. & 2009 & $\begin{array}{l}\text { Effects of light intensity, stocking density, feeding frequency and } \\
\text { salinity on the growth of sub-adult seahorses Hippocampus erectus } \\
\text { Perry, } 1810\end{array}$ & Aquaculture & us \\
\hline
\end{tabular}

$\begin{array}{lllll}\text { H. comes } & \text { H. histrix } \quad \text { H. kuda } \quad \text { H. spinosissimus } & \text { H. kelloggi } & \text { H. trimaculatus H. mohnikei }\end{array}$




\begin{tabular}{|c|c|c|c|c|c|c|c|c|}
\hline Lin, Q. & 2009 & $\begin{array}{l}\text { Weaning of juvenile seahorses Hippocampus erectus Perry, } 1810 \text { from } \\
\text { live to frozen food }\end{array}$ & Aquaculture & H. erectus & & & & \\
\hline Lin, Q. & 2009 & $\begin{array}{l}\text { Biochemical composition of the wild and cultured seahorses, } \\
\text { Hippocampus kuda Bleeker and Hippocampus trimaculatus Leach }\end{array}$ & Aquaculture Research & H. kuda & H. trimaculatus & & & \\
\hline Lin, Q. & 2009 & $\begin{array}{l}\text { Effects of substrate color, light intensity and temperature on survival } \\
\text { and skin color change of juvenile seahorses, Hippocampus erectus } \\
\text { Perry, } 1810\end{array}$ & Aquaculture & H. erectus & & & & \\
\hline Mai, A. C. G. & 2009 & $\begin{array}{l}\text { Aspectos ecológicos do cavalo-marinho Hippocampus reidi no estuário } \\
\text { Camurupim/Cardoso, Piaú, Brasil, fornecendo subsídios para a } \\
\text { criação de uma Área de Proteção Integral }\end{array}$ & Biota Neotropica & H. reidi & & & & \\
\hline Mattle, B. & 2009 & $\begin{array}{l}\text { Body size preferences in the pot-bellied seahorse Hippocampus } \\
\text { abdominalis: choosy males and indiscriminate females }\end{array}$ & $\begin{array}{l}\text { Behavioral Ecology and } \\
\text { Sociobiology }\end{array}$ & H. abdominalis & & & & \\
\hline Molina Dominguez, L. & 2009 & $\begin{array}{l}\text { Aquaculture and marine biodiversity boost: case examples from the } \\
\text { Canary Islands }\end{array}$ & $\begin{array}{l}\text { Water Resources } \\
\text { Management } \mathrm{V}\end{array}$ & H. hippocampus & & & & \\
\hline Murugan, A. & 2009 & $\begin{array}{l}\text { Breeding and mass-scale rearing of three spotted seahorse, } \\
\text { Hippocampus trimaculatus Leach under captive conditions }\end{array}$ & Aquaculture & H. trimaculatus & & & & \\
\hline Nadeau, J. L. & 2009 & $\begin{array}{l}\text { Preservation causes shrinkage in seahorses: implications for biological } \\
\text { studies and for managing sustainable trade with minimum size limits }\end{array}$ & $\begin{array}{l}\text { Aquatic Conservation- } \\
\text { Marine and Freshwater } \\
\text { Ecosystems }\end{array}$ & H. guttulatus & & & & \\
\hline Naud, Marie-Jose & 2009 & $\begin{array}{l}\text { Mate choice, operational sex ratio, and social promiscuity in a wild } \\
\text { population of the long-snouted seahorse Hippocampus guttulatus }\end{array}$ & Behavioral Ecology & H. guttulatus & & & & \\
\hline Roos, G. & 2009 & $\begin{array}{l}\text { Ontogeny of feeding kinematics in the seahorse Hippocampus reidi } \\
\text { from newly born to adult }\end{array}$ & $\begin{array}{l}\text { Integrative and Comparative } \\
\text { Biology }\end{array}$ & H. reidi & & & & \\
\hline Roos, G. & 2009 & Kinematics of suction feeding in the seahorse Hippocampus reidi & $\begin{array}{l}\text { Journal of Experimental } \\
\text { Biology }\end{array}$ & H. reidi & & & & \\
\hline Roos, G. & 2009 & $\begin{array}{l}\text { Linking Morphology and Motion: A Test of a Four-Bar Mechanism in } \\
\text { Seahorses }\end{array}$ & $\begin{array}{l}\text { Physiological and } \\
\text { Biochemical Zoology }\end{array}$ & H. reidi & & & & \\
\hline Ryu, B. M. & 2009 & $\begin{array}{l}\text { Purification of a peptide from seahorse, that inhibits arthritis-related } \\
\text { cytokines through MAPK/NF-kappa B activation, and induces human } \\
\text { osteoblastic and chondrocytic differentiation }\end{array}$ & Febs Journal & H. kuda & & & & \\
\hline Shokri, M. R. & 2009 & $\begin{array}{l}\text { The effectiveness of seahorses and pipefish (Pisces: Syngnathidae) as a } \\
\text { flagship group to evaluate the conservation value of estuarine seagrass } \\
\text { heds }\end{array}$ & $\begin{array}{l}\text { Aquatic Conservation- } \\
\text { Marine and Freshwater }\end{array}$ & H. spp. & & & & \\
\hline Storero, L. P. & 2009 & $\begin{array}{l}\text { Prey Selectivity and Trophic Behavior of the Patagonian Seahorse, } \\
\text { Hippocampus patagonicus, in Captivity }\end{array}$ & $\begin{array}{l}\text { Journal of the World } \\
\text { Aquaculture Society }\end{array}$ & H. patagonicus & & & & \\
\hline Teske, P. R. & 2009 & $\begin{array}{l}\text { Evolution of seahorses' upright posture was linked to Oligocene } \\
\text { expansion of seagrass habitats }\end{array}$ & Biology Letters & H. reidi & H. ingens & H. zosterae & H. breviceps & H. bargibanti \\
\hline van de Vliet, M. S. & 2009 & $\begin{array}{l}\text { Highly polymorphic microsatellite markers for the short-snouted } \\
\text { seahorse (Hippocampus hippocampus), including markers from a } \\
\text { closely related species the long-snouted seahorse (Hippocampus } \\
\text { guttulatus) }\end{array}$ & $\begin{array}{l}\text { Conservation Genetics } \\
\text { Resources }\end{array}$ & H. hippocampus & H. guttulatus & & & \\
\hline Van Wassenbergh, $\mathrm{S}$. & 2009 & Suction is kid's play: extremely fast suction in newborn seahorses & Biology Letters & H. reidi & & & & \\
\hline Van Wassenbergh, $\mathrm{S}$. & 2009 & $\begin{array}{l}\text { Pivot feeding performance in pipefish and seahorses analysed by } \\
\text { forward dynamic modelling }\end{array}$ & $\begin{array}{l}\text { Comparative Biochemistry } \\
\text { and Physiology a-Molecular } \\
\text { \& Integrative Physiology }\end{array}$ & Absent & & & & \\
\hline Woodall, L. C. & 2009 & $\begin{array}{l}\text { First occurrence of the lined seahorse Hippocampus erectus in the } \\
\text { eastern Atlantic Ocean }\end{array}$ & Journal of Fish Biology & H. erectus & & & & \\
\hline Zalohar, J. & 2009 & $\begin{array}{l}\text { Two new species of seahorses (Syngnathidae, Hippocampus) from the } \\
\text { Middle Miocene (Sarmatian) Coprolitic Horizon in Tunjice Hills, } \\
\text { Slovenia: The oldest fossil record of seahorses }\end{array}$ & Annales De Paleontologie & H. sarmaticus & H. slovenicus & & & \\
\hline Baine, M. S. P. & 2008 & $\begin{array}{l}\text { Residence and movement of pyymy seahorses, Hippocampus } \\
\text { bargibanti, on sea fans (Muricella spp.) }\end{array}$ & Coral reefs & H. bargibanti & & & & \\
\hline Bijukumar, A. & 2008 & $\begin{array}{l}\text { MORPHOMETRY AND MERISTICS OF LONGNOSE SEAHORSE, } \\
\text { HIPPOCAMPUS TRIMACULATUS (ACTINOPTERYGII: } \\
\text { SYNGNATHIDAE), FROM KERALA, SOUTH-WEST COAST OF } \\
\text { INDIA }\end{array}$ & $\begin{array}{l}\text { Acta Ichthyologica Et } \\
\text { Piscatoria }\end{array}$ & H. trimaculatus & & & & \\
\hline Bruner, E. & 2008 & Morphological Variation in the Seahorse Vertebral System & $\begin{array}{l}\text { International Journal of } \\
\text { Morphology }\end{array}$ & H. hippocampus & & & & \\
\hline
\end{tabular}




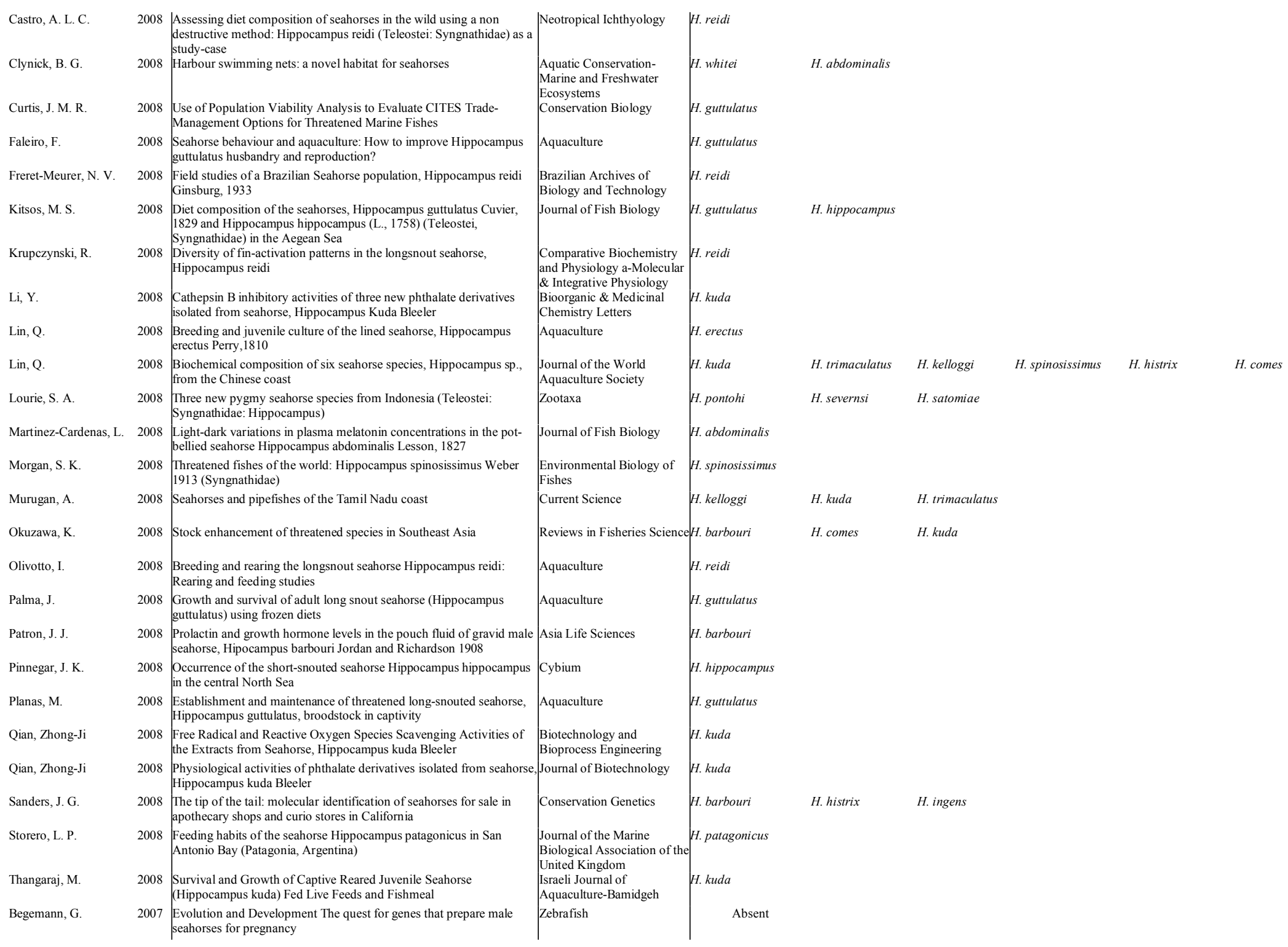




\begin{tabular}{|c|c|c|c|c|c|}
\hline Curtis, J. M. R. & 2007 & $\begin{array}{l}\text { A conservation trade-off? Interspecifici differences in seahorse } \\
\text { responses to experimental changes in fishing effort }\end{array}$ & \begin{tabular}{|l} 
Aquatic Conservation- \\
Marine and Freshwater \\
Ecosystems
\end{tabular} & H. hipросатриs & H. guttulatus \\
\hline Curtis, J. M. R. & 2007 & $\begin{array}{l}\text { Validation of a method for estimating realized annual fecundity in a } \\
\text { multiple spawner, the long-snouted seahorse (Hippocampus } \\
\text { guttulatus), using underwater visual census }\end{array}$ & Fishery Bulletin & H. guttulatus & \\
\hline Galbusera, P. H. A. & 2007 & $\begin{array}{l}\text { Isolation of microsatellite markers for the endangered Knysna seahorse } \\
\text { Hippocampus capensis and their use in the detection of a genetic } \\
\text { bottleneck }\end{array}$ & Molecular Ecology Notes & H. capensis & \\
\hline Gurkan, Sule & 2007 & $\begin{array}{l}\text { Length-weigth relationships for syngnathid fishes of the Aegean Sea, } \\
\text { Turkey }\end{array}$ & Belgian Journal of Zoology & H. hippocampus & H. guttulatus \\
\hline Jung, Min-Min & 2007 & Coexisting Fish Fauna in the Seahorse Habitats & Journal of Aquaculture & H. mohnikei & H. coronatus \\
\hline Kvarnemo, C. & 2007 & $\begin{array}{l}\text { Sexually selected females in the monogamous Western Australian } \\
\text { seahorse }\end{array}$ & $\begin{array}{l}\text { Proceedings of the Royal } \\
\text { Society B-Biological } \\
\text { Sciences }\end{array}$ & H. subelongatus & \\
\hline Lin, Q. & 2007 & $\begin{array}{l}\text { The effects of food and the sum of effective temperature on the } \\
\text { embryonic development of the seahorse, Hippocampus kuda Bleeker }\end{array}$ & Aquaculture & H. kuda & \\
\hline Lipton, A. P. & 2007 & $\begin{array}{l}\text { Evaluation of a simple tagging method to monitor the growth of } \\
\text { endangered species of seahorse }\end{array}$ & Current Science & H. kuda & \\
\hline Marcus, J. E. & 2007 & $\begin{array}{l}\text { Benthic status of near-shore fishing grounds in the central Philippines } \\
\text { and associated seahorse densities }\end{array}$ & Marine Pollution Bulletin & H. comes & \\
\hline Martinez-Cardenas, L. & 2007 & $\begin{array}{l}\text { Effect of tank colour on Artemia ingestion, growth and survival in } \\
\text { cultured early juvenile pot-bellied seahorses (Hippocampus } \\
\text { abdominalis) }\end{array}$ & Aquaculture & H. abdominalis & \\
\hline Morgan, S. K. & 2007 & $\begin{array}{l}\text { The ontogeny of habitat associations in the tropical tiger tail seahorse } \\
\text { Hippocampus comes Cantor, } 1850\end{array}$ & Journal of Fish Biology & H. comes & \\
\hline Mosk, V. & 2007 & $\begin{array}{l}\text { Spectral sensitivities of the seahorses Hippocampus subelongatus and } \\
\text { Hippocampus barbouri and the pipefish Stigmatopora argus }\end{array}$ & Visual Neuroscience & H. barbouri & H. subelongatus \\
\hline Pardo, B. G. & 2007 & $\begin{array}{l}\text { Novel microsatellite loci in the threatened European long-snouted } \\
\text { seahorse (Hippocampus guttulatus) for genetic diversity and parentage } \\
\text { analysis }\end{array}$ & Conservation Genetics & H. guttulatus & \\
\hline Roos, G. & 2007 & $\begin{array}{l}\text { High-speed kinematics of feeding behavior in the seahorse } \\
\text { Hippocampus reidi }\end{array}$ & Journal of Morphology & H. reidi & \\
\hline Rosa, I. L. & 2007 & $\begin{array}{l}\text { Population characteristics, space use and habitat associations of the } \\
\text { seahorse Hippocampus reidi (Teleostei : Syngnathidae) }\end{array}$ & Neotropical Ichthyology & H. reidi & \\
\hline Sheng, J. & 2007 & $\begin{array}{l}\text { Effect of starvation on the initiation of feeding, growth and survival } \\
\text { rate of juvenile seahorses, Hippocampus trimaculatus Leach and } \\
\text { Hippocampus kuda Bleeker }\end{array}$ & Aquaculture & H. trimaculatus & H. kuda \\
\hline Stoelting, K. N. & 2007 & $\begin{array}{l}\text { Male pregnancy in seahorses and pipefish: beyond the mammalian } \\
\text { model }\end{array}$ & Bioessays & H. spp. & \\
\hline Teske, P. R. & 2007 & $\begin{array}{l}\text { Hippocampus queenslandicus Horne, } 2001 \text { - a new seahorse species or } \\
\text { yet another synonym? }\end{array}$ & $\begin{array}{l}\text { Australian Journal of } \\
\text { Zoology }\end{array}$ & H. queenslandicus & \\
\hline Teske, P. R. & 2007 & $\begin{array}{l}\text { Does the endangered Knysna seahorse, Hippocampus capensis, have a } \\
\text { preference for aquatic vegetation type, cover or height? }\end{array}$ & African Zoology & H. capensis & \\
\hline Teske, P. R. & 2007 & $\begin{array}{l}\text { Signatures of seaway closures and founder dispersal in the phylogeny } \\
\text { of a circumglobally distributed seahorse lineage }\end{array}$ & Bmc Evolutionary Biology & H. spp. & \\
\hline Thangaraj, M. & 2007 & $\begin{array}{l}\text { Occurrence of the Japanese seahorse Hippocampus mohnikei Bleeker } \\
1854 \text { from the Palk Bay coast of south-eastern India }\end{array}$ & Journal of Fish Biology & H. mohnikei & \\
\hline Uyarra, Maria C. & 2007 & $\begin{array}{l}\text { The quest for cryptic creatures: Impacts of species-focused } \\
\text { recreational diving on corals }\end{array}$ & Biological Conservation & H. reidi & \\
\hline Van Look, K. J. W. & 2007 & $\begin{array}{l}\text { Dimorphic sperm and the unlikely route to fertilisation in the yellow } \\
\text { seahorse }\end{array}$ & $\begin{array}{l}\text { Journal of Experimental } \\
\text { Biology }\end{array}$ & H. kuda & \\
\hline Vasil'eva, E. D. & 2007 & Seahorse species (genus Hippocampus, pisces) described by C. Linne & Folia Zoologica & H. hippocampus & H. brevirostris \\
\hline Vincent, A & 2007 & $\begin{array}{l}\text { Characterizing a small-scale, data-poor, artisanal fishery: Seahorses in } \\
\text { the central Philippines }\end{array}$ & Fisheries Research & H. comes & \\
\hline
\end{tabular}




\begin{tabular}{|c|c|c|c|c|c|c|}
\hline Wilson, A. B. & 2007 & $\begin{array}{l}\text { Genetic monogamy despite social promiscuity in the pot-bellied } \\
\text { seahorse (Hippocampus abdominalis) }\end{array}$ & Molecular Ecology & H. abdominalis & & \\
\hline Wright, K. A. & 2007 & $\begin{array}{l}\text { Recovery from acute, chronic and transport stress in the pot-bellied } \\
\text { seahorse Hippocampus abdominalis }\end{array}$ & Journal of Fish Biology & H. abdominalis & & \\
\hline Alves, R. R. N. & 2006 & $\begin{array}{l}\text { From cnidarians to mammals: The use of animals as remedies in } \\
\text { fishing communities in NE Brazil }\end{array}$ & $\begin{array}{l}\text { Journal of } \\
\text { Ethnopharmacology }\end{array}$ & H. reidi & & \\
\hline Choo, C. K. & 2006 & $\begin{array}{l}\text { Morphological development and allometric growth patterns in the } \\
\text { juvenile seahorse Hippocampus kuda Bleeker }\end{array}$ & Journal of Fish Biology & H. kuda & & \\
\hline Curtis, J. M. R. & 2006 & $\begin{array}{l}\text { Life history of an unusual marine fish: survival, growth and movement } \\
\text { patterns of Hippocampus guttulatus Cuvier } 1829\end{array}$ & Journal of Fish Biology & H. guttulatus & & \\
\hline Curtis, J. M. R. & 2006 & $\begin{array}{l}\text { Visible implant elastomer color determination, tag visibility, and tag } \\
\text { loss: Potential sources of error for mark-recapture studies }\end{array}$ & $\begin{array}{l}\text { North American Journal of } \\
\text { Fisheries Management }\end{array}$ & H. guttulatus & & \\
\hline Curtis, J. M. R. & 2006 & $\begin{array}{l}\text { A case of mistaken identity: skin filaments are unreliable for } \\
\text { identifying Hippocampus guttulatus and Hippocampus hippocampus }\end{array}$ & Journal of Fish Biology & H. guttulatus & H. hippocampus & \\
\hline Do, Н. H. & 2006 & $\begin{array}{l}\text { Otolith morphology, microstructure and ageing in the hedgehog } \\
\text { seahorse, Hippocampus spinosissimus (Weber, 1913) }\end{array}$ & $\begin{array}{l}\text { Journal of Applied } \\
\text { Ichthyology }\end{array}$ & H. spinosissimus & & \\
\hline Dzyuba, B. & 2006 & $\begin{array}{l}\text { Effect of parental age and associated size on fecundity, growth and } \\
\text { survival in the yellow seahorse Hippocampus kuda }\end{array}$ & $\begin{array}{l}\text { Journal of Experimental } \\
\text { Biology }\end{array}$ & H. kuda & & \\
\hline Giles, B. G. & 2006 & The catch and trade of seahorses in Vietnam & $\begin{array}{l}\text { Biodiversity and } \\
\text { Conservation }\end{array}$ & H. spinosissimus & H. trimaculatus & H. kuda \\
\hline Hoffman, E. A. & 2006 & $\begin{array}{l}\text { Male pregnancy and the evolution of body segmentation in seahorses } \\
\text { and pipefishes }\end{array}$ & Evolution & Absent & & \\
\hline Job, S. & 2006 & Growth and survival of the tiger tail seahorse, Hippocampus comes & $\begin{array}{l}\text { Journal of the World } \\
\text { Aquaculture Society }\end{array}$ & H. comes & & \\
\hline Jung, Min-Min & 2006 & $\begin{array}{l}\text { Morphological Development, Growth and Survival of Barbour's } \\
\text { Seahorse,Hippocampus barbouri }\end{array}$ & $\begin{array}{l}\text { Journal of the Korean } \\
\text { Society of Oceanography }\end{array}$ & H. barbouri & & \\
\hline Karina, A. & 2006 & $\begin{array}{l}\text { Feeding behavior of the longsnout seahorse Hippocampus reidi } \\
\text { Ginsburg, } 1933\end{array}$ & Journal of Ethology & H. reidi & & \\
\hline Laksanawimol, P. & 2006 & $\begin{array}{l}\text { Alteration of the brood pouch morphology during gestation of male } \\
\text { seahorses, Hippocampus kuda }\end{array}$ & $\begin{array}{l}\text { Marine and Freshwater } \\
\text { Research }\end{array}$ & H. kuda & & \\
\hline Lin, $Q$. & 2006 & $\begin{array}{l}\text { The effect of temperature on gonad, embryonic development and } \\
\text { survival rate of juvenile seahorses, Hippocampus kuda Bleeker }\end{array}$ & Aquaculture & H. kuda & & \\
\hline Martin-Smith, K. M. & 2006 & $\begin{array}{l}\text { Exploitation and trade of Australian seahorses, pipehorses, sea dragons } \\
\text { and pipefishes (Family Syngnathidae) }\end{array}$ & soryx & Absent & & \\
\hline Meeuwig, J. J. & 2006 & Quantifying non-target seahorse fisheries in central Vietnam & Fisheries Research & H. spinosissimus & H. trimaculatus & \\
\hline Ortega-Salas, A. A. & 2006 & $\begin{array}{l}\text { Fecundity, survival, and growth of the seahorse Hippocampus ingens } \\
\text { (Pisces: Syngnathidae) under semi-controlled conditions }\end{array}$ & $\begin{array}{l}\text { Revista De Biologia } \\
\text { Tropical }\end{array}$ & H. ingens & & \\
\hline Rosa, I. L. & 2006 & $\begin{array}{l}\text { Collaborative monitoring of the ornamental trade of seahorses and } \\
\text { pipefishes (Teleostei : Syngnathidae) in Brazil: Bahia State as a case } \\
\text { study }\end{array}$ & Neotropical Ichthyology & H. reidi & H. erectus & \\
\hline Sheng, J. & 2006 & $\begin{array}{l}\text { Effects of food, temperature and light intensity on the feeding behavior } \\
\text { of three-spot juvenile seahorses, Hippocampus trimaculatus Leach }\end{array}$ & Aquaculture & H. trimaculatus & & \\
\hline Thangaraj, M. & 2006 & $\begin{array}{l}\text { Onset of sexual maturity in captive-reared endangered Indian seahorse, } \\
\text { Hippocampus kuda }\end{array}$ & Current Science & H. kuda & & \\
\hline Wilson, Z. & 2006 & $\begin{array}{l}\text { Nitrogen budgets for juvenile big-bellied seahorse Hippocampus } \\
\text { abdominalis fed Artemia, mysids or pelleted feeds }\end{array}$ & Aquaculture & H. abdominalis & & \\
\hline Baum, J. K. & 2005 & Magnitude and inferred impacts of the seahorse trade in Latin America & Environmental Conservation & Absent & & \\
\hline Braicovich, P. E. & 2005 & $\begin{array}{l}\text { First record of Corynosoma australe (Acanthocephala, Polymorphidae) } \\
\text { parasitizing seahorse, Hippocampus sp (Pisces, Syngnathidae) in } \\
\text { Patagonia (Argentina) }\end{array}$ & Acta Parasitologica & H. sp. & & \\
\hline Bruckner, A. W. & 2005 & $\begin{array}{l}\text { The importance of the marine ornamental reef fish trade in the wider } \\
\text { Caribbean }\end{array}$ & $\begin{array}{l}\text { Revista De Biologia } \\
\text { Tropical }\end{array}$ & H. zosterae & H. erectus & \\
\hline Collette, B. B. & 2005 & $\begin{array}{l}\text { Is the east-west division of haplotypes of the three-spot seahorse along } \\
\text { Wallace's Line novel among marine organisms? }\end{array}$ & Journal of Biogeography & H. trimaculatus & & \\
\hline
\end{tabular}




\begin{tabular}{|c|c|c|c|c|c|c|c|c|c|c|}
\hline Curtis, J. M. R. & 2005 & $\begin{array}{l}\text { Distribution of sympatric seahorse species along a gradient of habitat } \\
\text { complexity in a seagrass-dominated community }\end{array}$ & $\begin{array}{l}\text { Marine Ecology Progress } \\
\text { Series }\end{array}$ & H. guttulatus & H. hippocampus & & & & & \\
\hline Foster, S. J. & 2005 & $\begin{array}{l}\text { Enhancing sustainability of the international trade in seahorses with a } \\
\text { single minimum size limit }\end{array}$ & Conservation Biology & H. spp. & & & & & & \\
\hline Grey, M. & 2005 & Magnitude and trends of marine fish curio imports to the USA & Oryx & Absent & & & & & & \\
\hline Kendrick, A. J. & 2005 & $\begin{array}{l}\text { Variations in the dietary compositions of morphologically diverse } \\
\text { syngnathid fishes }\end{array}$ & $\begin{array}{l}\text { Environmental Biology of } \\
\text { Fishes }\end{array}$ & H. breviceps & H. subelongatus & & & & & \\
\hline Kim, Suam & 2005 & $\begin{array}{l}\text { Morphological Development and Reproductive Behavior of Hedgehog } \\
\text { Seahorse Hippocampus spinosissimus (Teleostei: Syngnathidae) }\end{array}$ & $\begin{array}{l}\text { Korean Journal of Fisheries } \\
\text { and Aquatic Sciences }\end{array}$ & H. spinosissimus & & & & & & \\
\hline Lourie, S. A. & 2005 & $\begin{array}{l}\text { Dispersal, habitat differences, and comparative phylogeography of } \\
\text { Southeast Asian seahorses (Syngnathidae : Hippocampus) }\end{array}$ & Molecular Ecology & H. barbouri & H. trimaculatus & H. kuda & H. spinosissimus & & & \\
\hline Martin-Smith, K. M. & 2005 & $\begin{array}{l}\text { Seahorse declines in the Derwent estuary, Tasmania in the absence of } \\
\text { fishing pressure }\end{array}$ & Biological Conservation & H. abdominalis & & & & & & \\
\hline Melamed, P. & 2005 & $\begin{array}{l}\text { The male seahorse synthesizes and secretes a novel C-type lectin into } \\
\text { the brood pouch during early pregnancy }\end{array}$ & Febs Journal & H. comes & & & & & & \\
\hline Monteiro, N. M. & 2005 & $\begin{array}{l}\text { Implications of different brood pouch structures in syngnathid } \\
\text { reproduction }\end{array}$ & $\begin{array}{l}\text { Journal of the Marine } \\
\text { Biological Association of the } \\
\text { United Kingdom }\end{array}$ & e. spp. & & & & & & \\
\hline Rosa, I. M. L. & 2005 & Fishers' knowledge and seahorse conservation in Brazil & $\begin{array}{l}\text { Journal of Ethnobiology and } \\
\text { Ethnomedicine }\end{array}$ & H. reidi & & & & & & \\
\hline Salin, K. R. & 2005 & Fisheries and trade of seahorses, Hippocampus spp., in southern India & $\begin{array}{l}\text { Fisheries Management and } \\
\text { Ecology }\end{array}$ & H. spp. & & & & & & \\
\hline Teske, P. R. & 2005 & $\begin{array}{l}\text { Molecular evidence for long-distance colonization in an Indo-Pacific } \\
\text { seahorse lineage }\end{array}$ & $\begin{array}{l}\text { Marine Ecology Progress } \\
\text { Series }\end{array}$ & H. kuda & H. fuscus & H. capensis & & & & \\
\hline Vandendriessche, $\mathrm{S}$. & 2005 & $\begin{array}{l}\text { Juvenile Hippocampus guttulatus from a neuston tow at the French- } \\
\text { Belgian border }\end{array}$ & Belgian Journal of Zoology & H. guttulatus & & & & & & \\
\hline Vincent, A. C. J. & 2005 & $\begin{array}{l}\text { Home range behaviour of the monogamous Australian seahorse, } \\
\text { Hippocampus whitei }\end{array}$ & $\begin{array}{l}\text { Environmental Biology of } \\
\text { Fishes }\end{array}$ & H. whitei & & & & & & \\
\hline Woods, C. M. C. & 2005 & $\begin{array}{l}\text { Evaluation of VI-alpha and PIT-tagging of the seahorse Hippocampus } \\
\text { abdominalis }\end{array}$ & Aquaculture International & H. abdominalis & & & & & & \\
\hline Woods, C. M. C. & 2005 & $\begin{array}{l}\text { Reproductive output of male seahorses, Hippocampus abdominalis, } \\
\text { from Wellington Harbour, New Zealand: implications for conservation }\end{array}$ & $\begin{array}{l}\text { New Zealand Journal of } \\
\text { Marine and Freshwater } \\
\text { Research }\end{array}$ & H. abdominalis & & & & & & \\
\hline Woods, C. M. C. & 2005 & $\begin{array}{l}\text { Growth of cultured seahorses (Hippocampus abdominalis) in relation } \\
\text { to feed ration }\end{array}$ & Aquaculture International & H. abdominalis & & & & & & \\
\hline Casey, S. P. & 2004 & $\begin{array}{l}\text { The origin and evolution of seahorses (genus Hippocampus): a } \\
\text { phylogenetic study using the cytochrome b gene of mitochondrial } \\
\text { DNA }\end{array}$ & $\begin{array}{l}\text { Molecular Phylogenetics and } \\
\text { Evolution }\end{array}$ & H. spp. & & & & & & \\
\hline Foster, S. J. & 2004 & $\begin{array}{l}\text { Life history and ecology of seahorses: implications for conservation } \\
\text { and management }\end{array}$ & Journal of Fish Biology & H. spp. & & & & & & \\
\hline Fricke, $R$. & 2004 & $\begin{array}{l}\text { Review of the pipefishes and seahorses (Teleostel: Syngnathidae) of } \\
\text { New Caledonia, with descriptions of five new species }\end{array}$ & $\begin{array}{l}\text { Stuttgarter Beitraege zur } \\
\text { Naturkunde Serie A } \\
\text { (Biologie) }\end{array}$ & H. spp. & & & & & & \\
\hline Goffredo, S. & 2004 & $\begin{array}{l}\text { Volunters in marine conservation monitoring: a study of the } \\
\text { distribution of seahorses carried out in collaboration with recreational } \\
\text { scuba divers }\end{array}$ & Conservation Biology & H. ramulosus & H. hippocampus & & & & & \\
\hline Kuang, C. C. & 2004 & $\begin{array}{l}\text { A record of seahorse species (family Syngnathidae) in East Malaysia, } \\
\text { with notes on their conservation }\end{array}$ & Malayan Nature Journal & H. trimaculatus & H. kuda & H. barbouri & H. kelloggi & H. comes & H. histrix & H. spinosissimus \\
\hline Kvarnemo, C. & 2004 & $\begin{array}{l}\text { Testes investment and spawning mode in pipefishes and seahorses } \\
\text { (Syngnathidae) }\end{array}$ & $\begin{array}{l}\text { Biological Journal of the } \\
\text { Linnean Society }\end{array}$ & H. spp. & & & & & & \\
\hline Lourie, S. A. & 2004 & $\begin{array}{l}\text { A marine fish follows Wallace's Line: the phylogeography of the } \\
\text { three-spot seahorse (Hippocampus trimaculatus, Syngnathidae, } \\
\text { Teleostei) in Southeast Asia }\end{array}$ & Journal of Biogeography & H. trimaculatus & & & & & & \\
\hline Martin-Smith, K. M. & 2004 & $\begin{array}{l}\text { Collaborative development of management options for an artisanal } \\
\text { fishery for seahorses in the central Philippines }\end{array}$ & $\begin{array}{l}\text { Ocean \& Coastal } \\
\text { Management }\end{array}$ & H. comes & & & & & & \\
\hline McPherson, J. M. & 2004 & $\begin{array}{l}\text { Assessing East African trade in seahorse species as a basis for } \\
\text { conservation under international controls }\end{array}$ & $\begin{array}{l}\text { Aquatic Conservation- } \\
\text { Marine and Freshwater }\end{array}$ & H. borboniensis & H. camelopardalis & H. fuscus & H. histrix & H. kelloggi & & \\
\hline
\end{tabular}




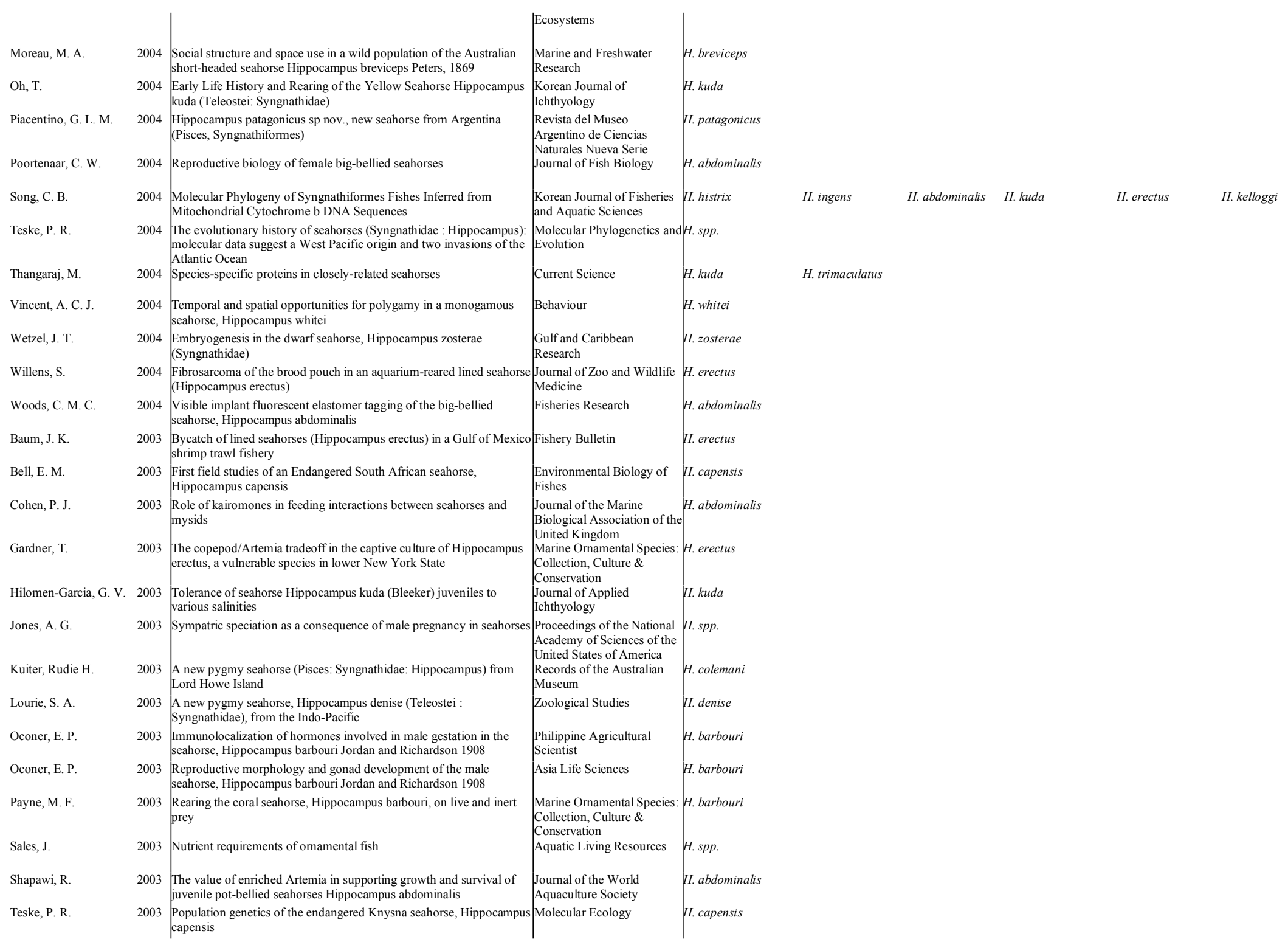




\begin{tabular}{|c|c|c|c|c|}
\hline Vincent, A. C. J. & 2003 & $\begin{array}{l}\text { Correlates of reproductive success in a wild population of } \\
\text { Hippocampus whitei }\end{array}$ & Journal of Fish Biology & H. whitei \\
\hline Wilson, A. B. & 2003 & $\begin{array}{l}\text { The dynamics of male brooding, mating patterns, and sex roles in } \\
\text { pipefishes and seahorses (family Syngnathidae) }\end{array}$ & Evolution & Absent \\
\hline Wong, J. M. & 2003 & $\begin{array}{l}\text { The effects of temperature, Artemia enrichment, stocking density and } \\
\text { light on the growth of juvenile seahorses, Hippocampus whitei } \\
\text { (Bleeker, 1855), from Australia }\end{array}$ & Aquaculture & H. whitei \\
\hline Woods, C. M. C. & 2003 & $\begin{array}{l}\text { Frozen mysids as an alternative to live Artemia in culturing seahorses } \\
\text { Hippocampus abdominalis }\end{array}$ & Aquaculture Research & H. abdominalis \\
\hline Woods, C. M. C. & 2003 & $\begin{array}{l}\text { Factors affecting successful culture of the seahorse, Hippocampus } \\
\text { abdominalis leeson, } 1827\end{array}$ & $\begin{array}{l}\text { Marine Ornamental Species: } \\
\text { Collection, Culture \& } \\
\text { Conservation }\end{array}$ & H. abdominalis \\
\hline Woods, C. M. C. & 2003 & $\begin{array}{l}\text { Effect of stocking density and gender segregation in the seahorse } \\
\text { Hippocampus abdominalis }\end{array}$ & Aquaculture & H. abdominalis \\
\hline Woods, C. M. C. & 2003 & $\begin{array}{l}\text { Effects of varying Artemia enrichment on growth and survival of } \\
\text { juvenile, seahorses, Hippocampus abdominalis }\end{array}$ & Aquaculture & H. abdominalis \\
\hline Woods, C. M. C. & 2003 & $\begin{array}{l}\text { Growth and survival of juvenile seahorse Hippocampus abdominalis } \\
\text { reared on live, frozen and artificial foods }\end{array}$ & Aquaculture & H. abdominalis \\
\hline Zhang, N. & 2003 & $\begin{array}{l}\text { Molecular profile of the unique species of traditional Chinese } \\
\text { medicine, Chinese seahorse (Hippocampus kuda Bleeker) }\end{array}$ & Febs Letters & H. kuda \\
\hline Ashley-Ross, M. A. & 2002 & $\begin{array}{l}\text { Mechanical properties of the dorsal fin muscle of seahorse } \\
\text { (Hippocampus) and pipefish (Syngnathus) }\end{array}$ & $\begin{array}{l}\text { Journal of Experimental } \\
\text { Zoology }\end{array}$ & Absent \\
\hline Carcupino, $\mathrm{M}$. & 2002 & $\begin{array}{l}\text { Functional significance of the male brood pouch in the reproductive } \\
\text { strategies of pipefishes and seahorses: a morphological and } \\
\text { ultrastructural comparative study on three anatomically different } \\
\text { pouches }\end{array}$ & Journal of Fish Biology & H. hippocampus \\
\hline Golani, D. & 2002 & $\begin{array}{l}\text { On the occurrence of Hippocampus fuscus in the eastern } \\
\text { Mediterranean }\end{array}$ & Journal of Fish Biology & H. fuscus \\
\hline Job, S. D. & 2002 & Culturing the oceanic seahorse, Hippocampus kuda & Aquaculture & H. kuda \\
\hline Perante, N. C. & 2002 & $\begin{array}{l}\text { Biology of a seahorse species, Hippocampus comes in the central } \\
\text { Philippines }\end{array}$ & Journal of Fish Biology & H. comes \\
\hline Rosa, I. L. & 2002 & $\begin{array}{l}\text { Threatened fishes of the world: Hippocampus reidi Ginsburg, } 1933 \\
\text { (Syngnathidae) }\end{array}$ & $\begin{array}{l}\text { Environmental Biology of } \\
\text { Fishes }\end{array}$ & H. reidi \\
\hline Schmid, M. S. & 2002 & Seahorses - Masters of adaptation & $\begin{array}{l}\text { Vie Et Milieu-Life and } \\
\text { Environment }\end{array}$ & Absent \\
\hline Woods, C. M. C. & 2002 & Natural diet of the seahorse Hippocampus abdominalis & $\begin{array}{l}\text { New Zealand Journal of } \\
\text { Marine and Freshwater } \\
\text { Research }\end{array}$ & H. abdominalis \\
\hline Adams, M. B. & 2001 & $\begin{array}{l}\text { Effect of acute and chronic ammonia and nitrite exposure on oxygen } \\
\text { consumption and growth of juvenile big bellied seahorse }\end{array}$ & Journal of Fish Biology & H. abdominalis \\
\hline Alcaide, E. & 2001 & Vibrio harveyi causes disease in seahorse, Hippocampus sp & Journal of Fish Diseases & H. kuda \\
\hline Consi, T. R. & 2001 & The dorsal fin engine of the seahorse (Hippocampus sp.) & Journal of Morphology & H. erectus \\
\hline deBruyn, A. M. H. & 2001 & $\begin{array}{l}\text { Detecting lunar cycles in marine ecology: periodic regression versus } \\
\text { categorical ANOVA }\end{array}$ & $\begin{array}{l}\text { Marine Ecology Progress } \\
\text { Series }\end{array}$ & H. spp. \\
\hline Horne, M. L. & 2001 & $\begin{array}{l}\text { A new seahorse species (Syngnathidae: Hippocampus) from the Great } \\
\text { Barrier Reef }\end{array}$ & $\begin{array}{l}\text { Records of the Australian } \\
\text { Museum }\end{array}$ & H. queenslandicus \\
\hline Jones, A. G. & 2001 & $\begin{array}{l}\text { Mating systems and sexual selection in male-pregnant pipefishes and } \\
\text { seahorses: Insights from microsatellite-based studies of maternity }\end{array}$ & Journal of Heredity & Absent \\
\hline Kanou, K. & 2001 & $\begin{array}{l}\text { Early life history of a seahorse, Hippocampus mohnikei, in Tokyo } \\
\text { Bay, Japan }\end{array}$ & Ichthyological Research & H. mohnikei \\
\hline Kornienko, E. S. & 2001 & $\begin{array}{l}\text { Reproduction and development of some pipefish and seahorse genera } \\
\text { of the family Syngnathidae }\end{array}$ & $\begin{array}{l}\text { Biologiya Morya } \\
\text { (Vladivostok) }\end{array}$ & H. spp. \\
\hline Kuiter, R. H. & 2001 & $\begin{array}{l}\text { Revision of the Australian seahorses of the genus Hippocampus } \\
\text { (Syngnathiformes: Syngnathidae) with descriptions of nine new } \\
\text { species }\end{array}$ & $\begin{array}{l}\text { Records of the Australian } \\
\text { Museum }\end{array}$ & H. spp. \\
\hline
\end{tabular}




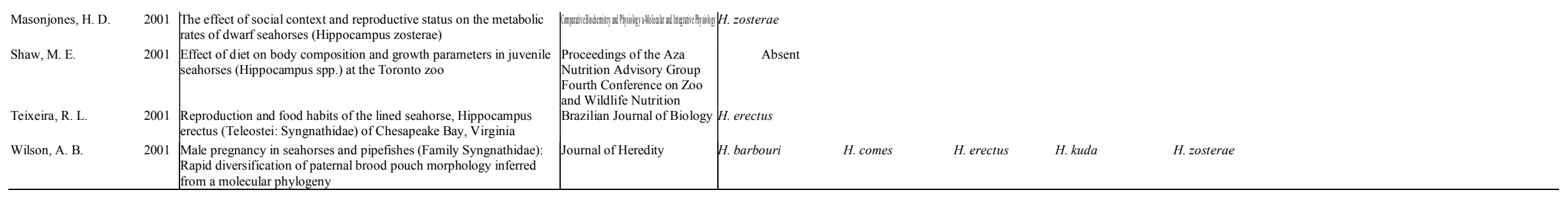

